\title{
Degassing regime of Hekla volcano 2012-2013
}

\author{
Evgenia Ilyinskaya $^{\mathrm{a}, \mathrm{b}, *}$, Alessandro Aiuppa ${ }^{\mathrm{c}, \mathrm{d}}$, Baldur Bergsson ${ }^{\mathrm{b}}$, \\ Rossella Di Napoli ${ }^{\mathrm{c}}$, Thráinn Fridriksson ${ }^{\mathrm{e}}$, Audur Agla Óladóttir ${ }^{\mathrm{e}}$, \\ Finnbogi Óskarsson ${ }^{\mathrm{e}}$, Fausto Grassa ${ }^{\mathrm{d}}$, Melissa Pfeffer ${ }^{\mathrm{b}}$, Katharina Lechner ${ }^{\mathrm{b}}$, \\ Richard Yeo ${ }^{\mathrm{b}}$, Gaetano Giudice ${ }^{\mathrm{d}}$ \\ ${ }^{a}$ British Geological Survey, Murchison House, West Mains Road, Edinburgh EH9 3LA, United Kingdom \\ ${ }^{\mathrm{b}}$ Icelandic Meteorological Office, Bustadavegi 7-9, 150 Reykjavik, Iceland \\ ${ }^{\mathrm{c}}$ DiSTeM, Università di Palermo, Palermo, Italy \\ ${ }^{\mathrm{d}}$ Istituto Nazionale di Geofisica e Vulcanologia, Sezione di Palermo, 90146 Palermo, Italy \\ ${ }^{\mathrm{e}}$ Iceland GeoSurvey, Grensasvegi 9, 108 Reykjavik, Iceland
}

Received 24 February 2014; accepted in revised form 9 January 2015; available online 17 February 2015

\begin{abstract}
Hekla is a frequently active volcano with an infamously short pre-eruptive warning period. Our project contributes to the ongoing work on improving Hekla's monitoring and early warning systems. In 2012 we began monitoring gas release at Hekla. The dataset comprises semi-permanent near-real time measurements with a MultiGAS system, quantification of diffuse gas flux, and direct samples analysed for composition and isotopes $\left(\delta^{13} \mathrm{C}, \delta \mathrm{D}\right.$ and $\left.\delta^{18} \mathrm{O}\right)$. In addition, we used reaction path modelling to derive information on the origin and reaction pathways of the gas emissions.

Hekla's quiescent gas composition was $\mathrm{CO}_{2}$-dominated $(0.8$ mol fraction $)$ and the $\delta^{13} \mathrm{C}$ signature was consistent with published values for Icelandic magmas. The gas is poor in $\mathrm{H}_{2} \mathrm{O}$ and $\mathrm{S}$ compared to hydrothermal manifestations and syn-eruptive emissions from other active volcanic systems in Iceland. The total $\mathrm{CO}_{2}$ flux from Hekla central volcano (diffuse soil emissions) is at least $44 \mathrm{~T} \mathrm{~d}^{-1}$, thereof $14 \mathrm{~T} \mathrm{~d}^{-1}$ are sourced from a small area at the volcano's summit. There was no detectable gas flux at other craters, even though some of them had higher ground temperatures and had erupted more recently.

Our measurements are consistent with a magma reservoir at depth coupled with a shallow dike beneath the summit. In the current quiescent state, the composition of the exsolved gas is substantially modified along its pathway to the surface through cooling and interaction with wall-rock and groundwater. The modification involves both significant $\mathrm{H}_{2} \mathrm{O}$ condensation and scrubbing of S-bearing species, leading to a $\mathrm{CO}_{2}$-dominated gas emitted at the summit. We conclude that a compositional shift towards more $\mathrm{S}$ - and $\mathrm{H}_{2} \mathrm{O}$-rich gas compositions if measured in the future by the permanent MultiGAS station should be viewed as sign of imminent volcanic unrest on Hekla.
\end{abstract}

(C) 2015 Published by Elsevier Ltd.

\footnotetext{
* Corresponding author at: British Geological Survey, Murchison House, West Mains Road, Edinburgh EH9 3LA, United Kingdom.
}

\section{INTRODUCTION}

Hekla volcano $\left(63.98^{\circ} \mathrm{N} 19.70^{\circ} \mathrm{W}\right)$ is one of the most frequently active, yet also one of the most unpredictable volcanoes in Europe, as a precursory seismic swarm has preceded its most recent eruptions by only a couple of hours or less (Soosalu and Einarsson, 2004). Five large Plinian eruptions ( $\geqslant 2 \mathrm{~km}^{3}$ of tephra) have been identified, 
with the most recent one in 1104 AD (Thorarinsson, 1967; Larsen et al., 1999). Following this event and until 1947 CE Hekla continued to erupt 1-2 times per century with volumes up to $0.4 \mathrm{~km}^{3}$ (Thorarinsson, 1950, 1967; Larsen et al., 1999). In recent decades, Hekla has erupted much more frequently and in significantly smaller events $\left(<0.1 \mathrm{~km}^{3}\right)$ : in 1970, 1980-1981, 1991 and 2000 (Thorarinsson and Sigvaldason, 1972; Gronvold et al., 1983; Gudmundsson et al., 1992; Höskuldsson et al., 2007). Since 2000, the volcano has been inflating and has already reached the elevation attained prior to the last eruption (Sturkell et al., 2005; Ofeigsson et al., 2011). It is unknown whether the frequent activity of Hekla in the last 40 years is a beginning of a new eruptive trend.

There is still a significant uncertainty about the depth of Hekla's magma source. Several early ground deformation studies inferred the magma reservoir depth at $5-10 \mathrm{~km}$ (Kjartansson and Gronvold, 1983; Sigmundsson et al., 1992), while a more recent and more encompassing work by Sturkell et al. (2013) locate it closer to $10 \mathrm{~km}$. However, other research has indicated that there is no significant molten material shallower than $14 \mathrm{~km}$ (Soosalu and Einarsson, 2004); and that the main storage chamber is located at $16 \pm 2 \mathrm{~km}$ depth (Ofeigsson et al., 2011), or possibly as deep as $24 \mathrm{~km}$ (Geirsson et al., 2012). Petrological analysis provides evidence in support of magma storage at $\sim 9 \mathrm{~km}$ (Moune et al., 2007).

Hekla's gas budget is not well constrained, but the available data indicate that significant gas quantities are emitted both during, and in between eruptive episodes. The 2000 eruption (the smallest eruption on record) is the best documented one in terms of gas release. TOMS, MODIS, and HIRS/2-TOVS satellite retrievals detected up to $0.3-$ $0.4 \mathrm{Tg}$ of $\mathrm{SO}_{2}$ released during the eruption (Rose et al., 2003), but petrological data suggests that the total released amount could have been up to 0.6-3.8 Tg (Moune et al., 2007). Hekla's syn-eruptive gas emissions have a notoriously high fluoride content (Oskarsson, 1980) which has led to fluoride poisoning in grazing animals; birds and livestock have also been reportedly killed by $\mathrm{CO}_{2}$ and $\mathrm{CO}$ degassing (Thorarinsson, 1967). Degassing of Hekla during quiescent intervals has been primarily investigated through analysis of groundwaters sourced in the area (Gislason et al., 1992; Flaathen and Gislason, 2007; Flaathen et al., 2009). The water alkalinity has been found to be one of the highest in Iceland, attributed to the contribution of magmatic $\mathrm{CO}_{2}$ gas and partial dissolution of volcanic bedrock (Flaathen and Gislason, 2007; Flaathen et al., 2009). The flux of $\mathrm{CO}_{2}$ from the Hekla system through groundwater dissolution has been estimated to be at least 100 $250 \mathrm{kT}$ per annum (Gislason et al., 1992; Flaathen and Gislason, 2007; Flaathen et al., 2009) but it was noted that this is a minimum estimate as an unknown proportion of $\mathrm{CO}_{2}$ may be lost from the system through different pathways. $\mathrm{CO}_{2}$ concentrations have not yet been petrologically determined for Hekla's magmas.

Since the summer of 2012 we have been collecting a semi-continuous data set in order to quantify Hekla's atmospheric gas emissions (measurements ongoing at the time of writing). This manuscript presents our first findings based on the data collected in 2012 (July-September) and 2013 (March-November), all made during a quiescent interval. Through analysis of the gas composition, gas flux and stable isotope content, we provide a novel constraint on the current gas output from Hekla system and its degassing pathways. Reaction path modelling is used to lend quantitative support to our conclusions about the gas origin. These data are highly complementary to measurements during past and any future eruptive episodes.

\section{METHODOLOGY}

\subsection{Field site description}

The Hekla central volcano (Hekla mountain) has been built up by repeated lava flows and tephra layers and has a morphology intermediate between that of a crater row and a stratovolcano: a cone elongated in the NE-SW direction (Fig. 1). The glacier-free summit reaches approximately $1490 \mathrm{~m}$ a.s.1. A central fissure runs along the volcano's longitudinal axis. The location of the active craters varies between eruption episodes (Fig. 1). Flank fissures have erupted basaltic magmas, while the magmas produced by the central fissure are more silicic. The composition has ranged from basaltic andesite through dacite (Gudmundsson et al., 1992).

At the time of our study, Hekla was in a quiescent state with no focused gas venting, but visible steam emanations were found in areas near its summit. The soil layer at Hekla is a mixture of basaltic sand and tephra; thin and presumed to be highly permeable to gases. Vegetation cover is non-existent bar very small areas of moss and lichen (Fig. 2), and the proportion of biogenic $\mathrm{CO}_{2}$ is thus assumed to be negligible. Across extensive parts of Hekla mountain, the top surface remained frozen and/or under snow cover throughout all seasons. In addition, in some areas a distinct layer of ice was found a few $\mathrm{cm}$ below the top tephra layer; this was believed to be compacted snow predating the 2000 eruption.

Weather conditions at the summit are variable, with atmospheric temperature $(T)$ between +5 and $-15^{\circ} \mathrm{C}$, relative humidity (RH) at 40-70\%, and highly changeable wind speed and direction.

\subsection{Ground temperature and diffuse $\mathrm{CO}_{2}$ degassing}

The ground temperature $\left(T_{\mathrm{G}}\right)$ and diffuse carbon dioxide flux through soil $\left(\varphi_{\mathrm{CO}_{2}}\right)$ were measured on Hekla's flanks and summit in the summer months of 2012 and 2013.

In 2012, the measurements were collected over 7 days when the seasonal snow cover was at its minimum. The summit area was mapped out on a $10 \times 10 \mathrm{~m}$ grid with a total of 337 measurements (Table 1). Grid-based measurements were unfortunately not made at Öxl crater due to difficulty with access. Non-grid based measurements were also made in different locations on the Hekla mountain in areas free of snow cover, including two other recently active craters (Fig. 3). $T_{\mathrm{G}}$ in all of those areas was equal to, or lower than atmospheric $T$. The ground was commonly frozen and/or there was an underlying fossil ice layer. 


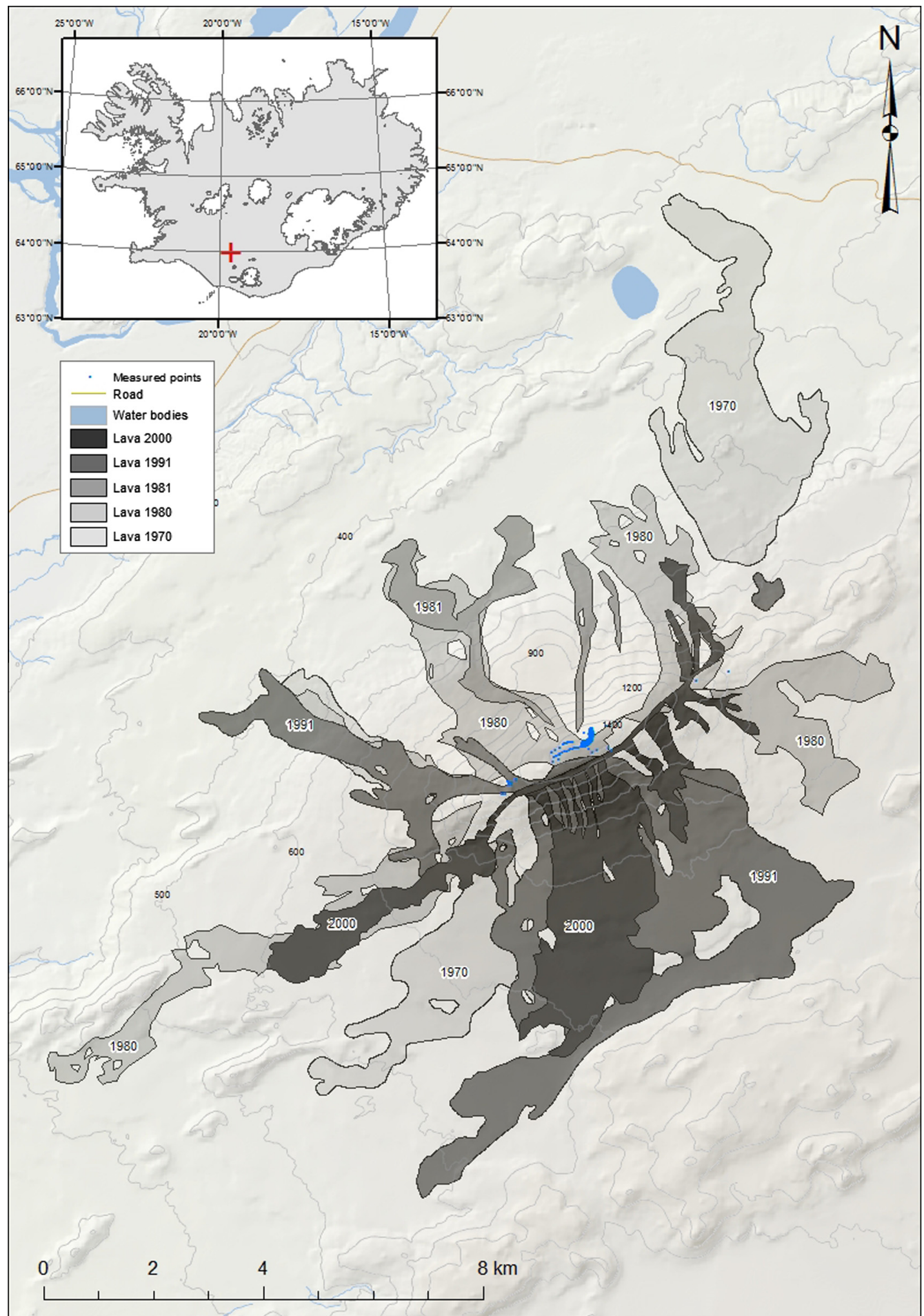

Fig. 1. Lava flows produced in the small and frequent eruptions of Hekla since 1970. The location of the principal eruptive vents has varied somewhat between eruptions, although they are invariably located parallel to the longitudinal axis of the volcano. The summit crater has not produced eruptive material since the 1980-81 eruption. Blue points along the summit of Hekla indicate measurement locations of this study.(For interpretation of the references to colour in this figure legend, the reader is referred to the web version of this article.) 


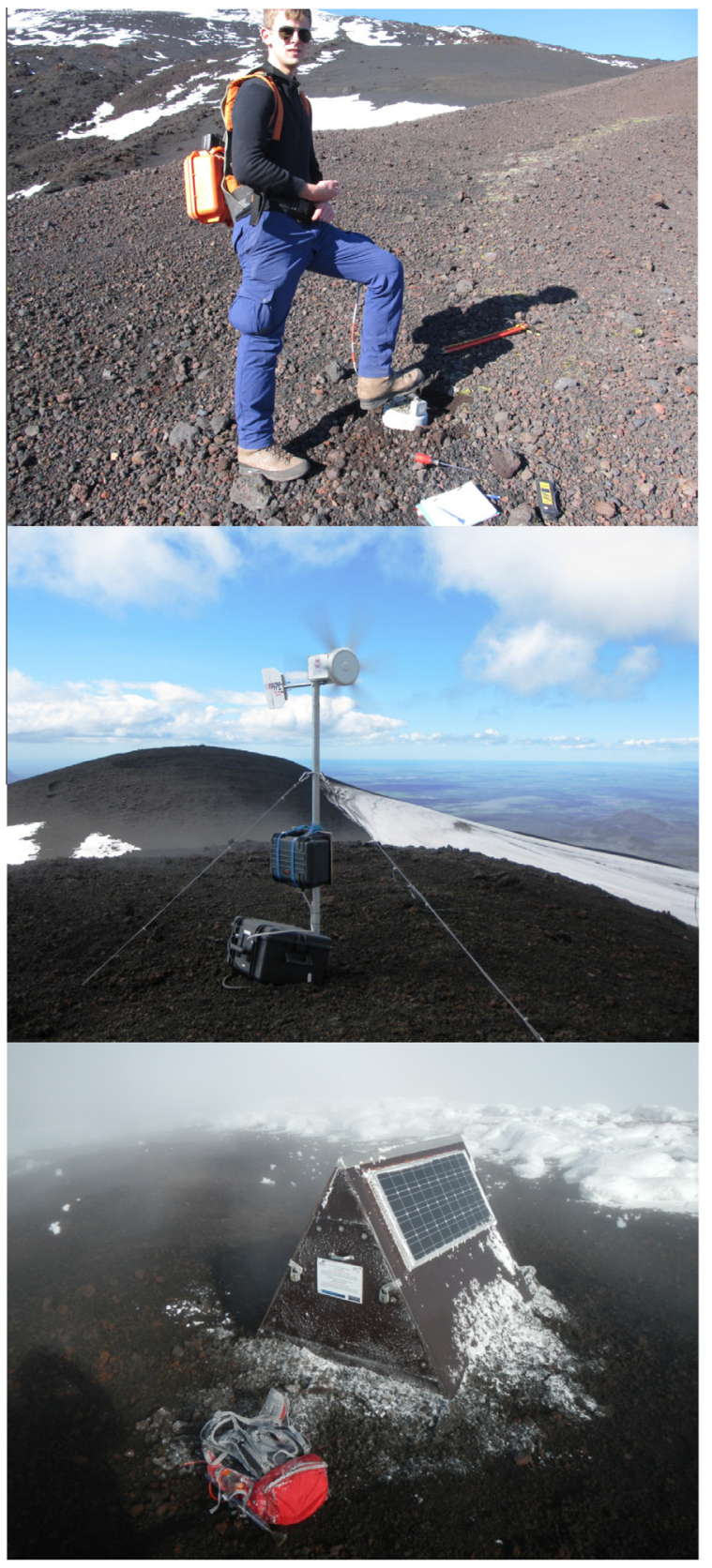

Fig. 2. Field photographs from Hekla. The surface is covered with basaltic tephra and is essentially vegetation-free. Certain areas at the summit have elevated ground temperature and remain snowfree during all seasons. Top image: Diffuse flux of $\mathrm{CO}_{2}$ through soil was measured using a closed-chamber portable instrument from WestSystems. The instrument is carried in a backpack and operated using a wireless palm-top computer. Middle image: Temporary installation (July-September 2012) of MultiGAS station at the summit of Hekla. The station was attached to the wind turbine mast and the batteries were on the ground. Bottom image: Permanent installation (March 2013 - ongoing) of MultiGAS station at the summit of Hekla. The station and batteries are housed inside the hut which is equipped with a solar panel. The permanent installation eliminates the problem of icing.

In 2013, the measurements of $T_{\mathrm{G}}$ and $\varphi_{\mathrm{CO}_{2}}$ were repeated at the summit. Due to unfavourable weather conditions throughout the summer of 2013, we were unable to do this until late September, which meant that the seasonal snow cover was significantly more extensive than when the measurements were made in 2012. The measurements were therefore made only along the longitudinal axis of the summit (215 m long, 42 measurement points), which is the hottest area of Hekla mountain and consequently snow-free (Fig. 3). Whereas the total number of measurements was lower in 2013, these data allow comparison with those from 2012 for the area of highest $T_{\mathrm{G}}$ and $\varphi_{\mathrm{CO}_{2}}$.

Ground temperature reading was taken at $10 \mathrm{~cm}$ depth using Atkins AccuTuff PLUS 330 thermometer $\left( \pm 0.5^{\circ} \mathrm{C}\right)$. The $\varphi_{\mathrm{CO}_{2}}$ was measured directly using a closed-chamber portable $\mathrm{CO}_{2}$ flux meter (Fig. 2) from WestSystems (described in Fridriksson et al., 2006). The measurements were only conducted when dry weather conditions had prevailed for at least $36 \mathrm{~h}$ in order to avoid potential effects of water saturation of the soil pores (Granieri et al., 2003). In 2012 , as the area was mapped out over seven days, $T_{\mathrm{G}}$ and $\varphi_{\mathrm{CO}_{2}}$ were measured each day at a selected reference point at the summit in order to identify any fluctuations (Table 1).

Generally, $\varphi_{\mathrm{CO}_{2}}$ was either very low or below detection limits where $T_{\mathrm{G}}$ was at ambient levels (Table 1). As shown on Fig. 3, our measurements omit large parts of the Hekla mountain, and the maps of $T_{\mathrm{G}}$ and $\varphi_{\mathrm{CO}_{2}}$ are as such incomplete. See Section 3 for the estimate of $\varphi_{\mathrm{CO}_{2}}$ from the unmapped areas.

\subsection{Multicomponent Gas Analyzer System}

\subsubsection{Temporary installation in 2012}

A Multicomponent Gas Analyzer System (MultiGAS) station was installed at the summit of Hekla on 4 July 2012. The station was installed in the location with the highest gas emissions as identified by the $\mathrm{CO}_{2}$ ground flux mapping (Fig. 3). Data collection was stopped in early September 2012 due to persistent icing of the powergenerating wind turbine.

The INGV-type MultiGAS (Aiuppa et al., 2009, 2010) is based on custom-made technology, and was equipped with an infrared spectrometer for $\mathrm{CO}_{2}$ (Edinburgh Instruments, Gascard NG, 0-1\%), three specific electrochemical sensors for $\mathrm{H}_{2} \mathrm{~S}, \mathrm{SO}_{2}$ and $\mathrm{H}_{2}$ sensing $(0-50 \mathrm{ppm}$ EZ3H, 0$200 \mathrm{ppm} 3 \mathrm{ST} / \mathrm{F}$, and 0-200 ppm EZT3HYT 'Easy Cal' respectively; all by City Technology Ltd.,) and a Vaisala RH sensor (which, when combined with co-measured pressure and temperature, allows for calculation of $\mathrm{H}_{2} \mathrm{O}$ concentrations of the volcanic emissions). All sensors were located inside a rugged plastic box, which also contained a STMicroelectronics microcontroller commanding acquisition, processing and storage of sensors' outputs. The station was powered by two $12 \mathrm{~V} 40 \mathrm{Ah}$ battery, and a wind turbine mounted on a mast (Fig. 2). The sampling intake was raised by $\sim 20 \mathrm{~cm}$ above ground level, which was necessary to avoid saturation of the $\mathrm{CO}_{2}$ sensor. The gas emanating from the soil (mixed with ambient air) was pumped to the sensors (using an onboard $1.21 \mathrm{~min}^{-1}$ pump), via a PTFE filter and a $1 \mathrm{~m}$-long PTFE tube. The instrument 
Table 1

Summary of $\mathrm{CO}_{2}$ flux and ground temperature $\left(T_{\mathrm{G}}\right)$ measurements at Hekla. Values of $\mathrm{CO}_{2}$ flux are reported to 3 significant figures. Summit: Measurements in 2012 were made on a $10 \times 10 \mathrm{~m}$ grid. In 2013 we were only able to collect one longitudinal profile along the summit, which does not allow the total gas flux to be calculated. The mean( $\left(^{*}\right)$ values for 2012 and 2013 are calculated based only on points measured along a longitudinal profile in the high-emission area at the summit (see Fig. 3); this allows a realistic comparison between 2012 and 2013. Öxl crater: The grid area is given as an estimate only as accurate grid measurements were not possible due to difficult access. Other areas: These are subdivided into areas with $T_{\mathrm{G}}$ elevated significantly above ambient $T$, and areas where $T_{\mathrm{G}}$ was close to ambient $\left(\sim 0-4{ }^{\circ} \mathrm{C}\right)$. These areas were measured in 2012 only, as scattered points.

\begin{tabular}{|c|c|c|c|c|c|c|c|c|c|}
\hline \multirow[t]{2}{*}{ Location } & \multicolumn{2}{|c|}{ Measured area } & \multicolumn{2}{|c|}{$\begin{array}{l}T_{\mathrm{G}} \text { at } 10 \mathrm{~cm} \\
\text { depth }\end{array}$} & \multicolumn{5}{|l|}{$\mathrm{CO}_{2}$ flux } \\
\hline & $\begin{array}{l}\text { Grid area } \\
\left(\mathrm{m}^{2}\right)\end{array}$ & $\begin{array}{l}n \text { of } \\
\text { points }\end{array}$ & $\begin{array}{l}\operatorname{Max} \\
\left({ }^{\circ} \mathrm{C}\right)\end{array}$ & $\begin{array}{l}\text { Mean } \\
\left({ }^{\circ} \mathrm{C}\right)\end{array}$ & $\begin{array}{l}\operatorname{Max} \\
\left(\mathrm{g} \mathrm{m}^{-2} \mathrm{~d}^{-1}\right)\end{array}$ & $\begin{array}{l}\text { Mean } \\
\left(\mathrm{g} \mathrm{m}^{-2} \mathrm{~d}^{-1}\right)\end{array}$ & $\begin{array}{l} \pm \text { at reference } \\
\text { point }(\%)\end{array}$ & $\begin{array}{l}\text { Total } \\
\left(\mathrm{t} \mathrm{d}^{-1}\right)\end{array}$ & $\begin{array}{l} \pm \\
\left(\mathrm{t} \mathrm{d}^{-1}\right)\end{array}$ \\
\hline Summit (2012) & 30,000 & 254 & 56.8 & $32.7^{*}$ & 23,060 & $3960^{*}$ & 17.5 & 13.7 & 3.7 \\
\hline Summit (2013) & $\begin{array}{l}\text { Profile } \\
(215 \mathrm{~m})\end{array}$ & 42 & 53.2 & $33.6^{*}$ & 22,300 & $5560^{*}$ & - & - & - \\
\hline Öxl crater (2012) & $\sim 5000$ & 16 & 71.5 & 28.5 & 45.3 & 4.87 & - & - & - \\
\hline $\begin{array}{l}\text { Other areas - elevated } \\
T_{\mathrm{G}}(2012)\end{array}$ & $\begin{array}{l}\text { Scattered } \\
\text { points }\end{array}$ & 7 & 27.2 & 16.7 & 158 & 40.1 & - & - & - \\
\hline $\begin{array}{l}\text { Other areas - ambient } \\
T_{\mathrm{G}}(2012)\end{array}$ & $\begin{array}{l}\text { Scattered } \\
\text { points }\end{array}$ & 60 & 4.70 & 0.554 & 118 & 12.7 & - & - & - \\
\hline
\end{tabular}

was configured to acquire in cycles of 200 samples, each being the median of 9 measures @ $1 \mathrm{~Hz}$ (30 min per sampling cycle). A time interval of $6 \mathrm{~h}$ between sampling cycles was set. A $3 \mathrm{G}$ radio modem was used for telemetry, and data were retrieved remotely using custom-made software.

\subsubsection{Permanent installation in 2013}

The MultiGAS station was reinstalled on 30 March 2013 and was still in operation at the time of writing. The data discussed in this manuscript are from the period 30 March-12 November. This set-up of the station follows a new design which eliminates the problem of icing and allows measurements to be collected year-round. This winterised design has since been replicated at the summit of Etna (G. Giudice, pers. comm., May 2013). The station is housed in a small triangular hut constructed from $12 \mathrm{~mm}$ thick water-resistant plywood (Fig. 2). The hut has the footprint of $150 \times 150 \mathrm{~cm}$ with the height of $\sim 130 \mathrm{~cm}$ and is insulated with $45 \mathrm{~mm}$ thick Styrofoam. Three $12 \mathrm{~V}$ $200 \mathrm{Ah}$ AGM batteries connected in parallel with a $90 \mathrm{~W}$ solar panel fitted to the roof of the hut supply the station with power all year round. The MultiGAS station is located inside the hut on the floor with the inlet inserted directly into the soil under the hut, which gives it additional shelter from the elements and eliminates the problem of icing. Shortly after the installation of the instrument a problem with vapour condensation inside the instrument was noticed. This was solved by installing a heat-coil in the inlet of the station which reduces condensation. In addition, the station warms up for 30 min before gas is sampled in order to increase its internal temperature.

The station is equipped with the same sensors as in 2012, except that it has no $\mathrm{H}_{2}$ sensor (the $\mathrm{H}_{2}$ sensor does not tolerate the very water-vapour rich environment that was unavoidable in the set-up of the permanent station), and a new $\mathrm{CO}_{2}$ sensor with detection range 0-10\% (Edinburgh Instruments, Gascard NG) as the gas emissions are less diluted by background air in the current set-up. The sensors were replaced with new ones in July 2013. The telemetry has also been improved by using a directional antenna located inside the hut to avoid icing.

The general power requirements of the station is $1 \mathrm{Ah}$ per 30 min sampling cycle, additionally the $3 \mathrm{G}$ router draws 4.8 Ah per day so the station consumes about 8.8 Ah per day based on 4 sampling cycles per day. At the current power consumption the station can last for about 68 days without any recharging from the solar panel, however, power saving options in the $3 \mathrm{G}$ router and alteration of the sampling frequency can increase this no-charge lifetime up to 150 days or more.

\subsection{Direct gas sampling and analysis}

Samples of both dry gas and condensate were collected in the summit crater area (Fig. 3) in September 2012. The sampling procedure was very time consuming due to low gas pressure, and the obtained sample number was low ( $n=5$ for dry gas and $n=2$ for condensate). Dry gas sampling for $\delta^{13} \mathrm{C}$ analysis was repeated in September 2013 ( $n=25$, thereof $n=2$ analysed for composition). Condensate sampling was not repeated in 2013 due to time constraints, as the procedure is very time consuming and daylight was already limited at that time of year. Sampling should ideally be repeated during the summer months.

\subsubsection{Sampling procedure in 2012}

Samples were collected from 2 sites within $10 \mathrm{~m}$ from the MultiGAS station on 19 September 2012 by using a $1.5 \mathrm{~m}$ long 3/4" wide plastic probe, the lower half of which had been perforated to allow inflow of gas. The probe was inserted into the ground to a depth of $\sim 130 \mathrm{~cm}$ and a plastic sheet was spread on the ground around the pipe in order to focus the diffuse gas emissions. Condensate samples $(n=2)$ were collected via silicone rubber tubing in a polypropylene suction flask and decanted into amber glass bottles. Dry gas samples for compositional analysis $(n=5)$ were collected using two methods. Three samples were 

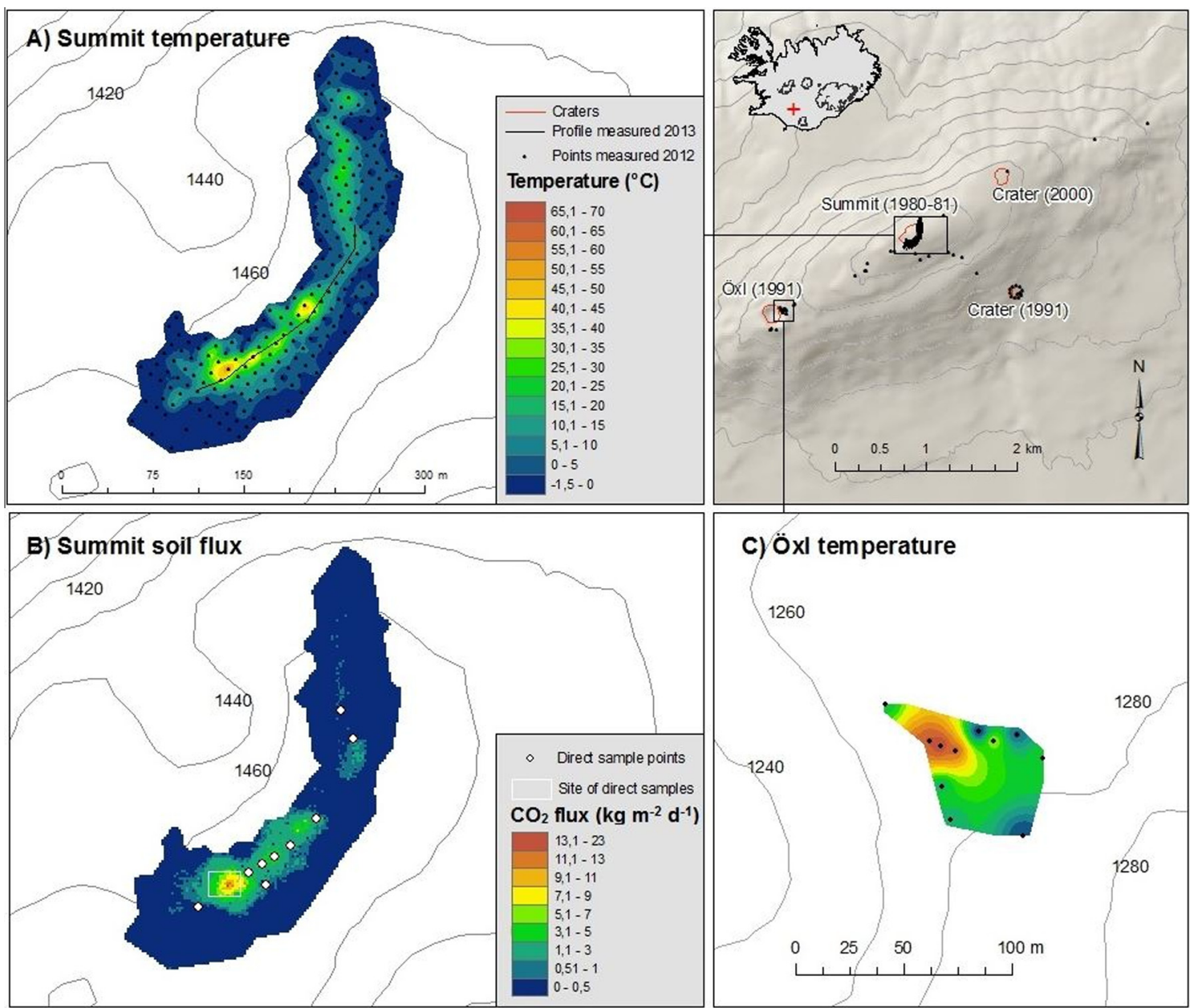

Fig. 3. Distribution of ground temperature $\left(T_{\mathrm{G}}\right)$ and $\mathrm{CO}_{2}$ soil flux at Hekla volcano. Measurements were made near four previously active craters (overview map, top right); the year of the most recent eruption at each crater is shown in parentheses. $T_{\mathrm{G}}$ was found to be elevated above background $\left(-1.5-0{ }^{\circ} \mathrm{C}\right)$ at the summit $(\mathrm{A})$ and Öxl craters $(\mathrm{C}) . T_{\mathrm{G}}$ at all other measured points was at background level. At the summit crater, grid measurements were made in 2012, but only a single profile (42 points) in 2013. Figure B shows the modelled diffuse $\mathrm{CO}_{2}$ soil flux from the summit area of Hekla $\left(\mathrm{kg} \mathrm{m}^{-2} \mathrm{~d}^{-1}\right)$. The map shows average flux value for each model cell. No other areas at Hekla were found to have an elevated $\mathrm{CO}_{2}$ flux. The locations of the direct sampling collection are labelled with white dots. Additional 10 samples were collected within the white rectangle (not shown individually to improve visual clarity). The MultiGAS station is located at the highest $\mathrm{CO}_{2}$ soil flux point $\left(23 \mathrm{~kg} \mathrm{~m}^{-2} \mathrm{~d}^{-1}\right)$.

collected by using the gas pressure to displace an acidified saturated $\mathrm{NaCl}$ solution from a double-port glass tube. Two samples were collected by filling previously evacuated $(<0.1$ torr $)$ glass flasks with two Teflon valves by using a plastic syringe of $100 \mathrm{cc}$ equipped with a three-way stopcock.

\subsubsection{Sampling procedure in 2013}

Samples $(n=25)$ were collected from 17 sites in the summit crater area on 24 September 2013. In addition, one sample of background air was obtained at Hekla in an area judged to be unaffected by the volcanic emissions. The sampling of volcanic emissions was done by using a $1.2 \mathrm{~m}$ long metallic probe, the lower half of which had been perforated to allow inflow of gas. The probe was inserted into the ground to a depth of $\sim 100-110 \mathrm{~cm}$ and the gas was collected using two different methods. Two pressurized (around 2 bars) samples for compositional analysis were collected in glass vials with two Teflon valves by using a plastic syringe of $100 \mathrm{cc}$ equipped with a three-way stopcock. Fifteen more sites were sampled (some in duplicate) using screw capped $12 \mathrm{ml}$ vials $\left(\mathrm{LABCO}^{\circledR}\right)$ with pierceable rubber septum. Vials were filled with gas collected by producing a very small negative pressure in the probe using a pump at a constant flux $\left(100 \mathrm{cc} \mathrm{min}^{-1}\right)$. The concentration of $\mathrm{CO}_{2}$ was subsequently measured in all samples using a portable gas detector IR spectrophotometer (Edinburgh Instruments, Gascard NG, full scale 10\%). The method used to collect samples for compositional analysis yielded slightly higher values of $\mathrm{CO}_{2}(\%)$ compared with 2012 (Table 2), which indicates a lower degree of mixing with background air. This is not considered to impact the principal purpose of this sampling campaign, which was to measure $\delta^{13} \mathrm{C}$ in Hekla emissions. For both types of sampling methods, the $\mathrm{CO}_{2}$ concentration was $\sim 2$ orders of magnitude higher than background $\mathrm{CO}_{2}$, and therefore 
Table 2

Composition of Hekla dry gas samples (YYYY Dry-n), gas condensates (2012-Cond- $n$ ), fresh snow (2012 only), and ambient air (2013 only). Full analysis results can be found in Appendix I. The snow and ambient air samples were collected away from the influence of volcanic emissions, and are believed to represent the composition of the local meteoric water and the atmosphere, respectively. All dry gas samples show high degree of mixing with background air, but there is a stronger 'volcanic' gas signal in the 2013 samples due to improved sampling set-up. Ratios between the "volcanic' gas species show no significant difference 2012 and 2013 based on their standard deviation. "GC" = gas chromatography, "IR" = portable IR spectrophotometer, "_" = not analysed, "b.d.l." = below detection limits.

\begin{tabular}{|c|c|c|c|c|c|}
\hline Sample type & Dry gas $2012(\mu \pm \sigma)$ & Dry gas $2013(\mu \pm \sigma)$ & Ambient air & Condensate gas $(\mu \pm \sigma)$ & Fresh snow \\
\hline $\mathrm{N}_{2}(\%)$ & $76.6 \pm 0.7$ & $74.4 \pm 0.8$ & - & - & - \\
\hline $\mathrm{O}_{2}(\%)$ & $18.9 \pm 0.3$ & $19.1 \pm 0.5$ & - & - & - \\
\hline $\mathrm{CO}_{2}(\%) \mathrm{GC}$ & $2.91 \pm 1$ & $5.65 \pm 0.4$ & - & - & - \\
\hline $\mathrm{CO}_{2}(\%) \mathrm{IR}$ & - & $2.03 \pm 2$ & 0.035 & - & - \\
\hline $\mathrm{CO}(\mathrm{ppm})$ & $2.3 \pm 0.6$ & $11.9 \pm 4$ & - & - & - \\
\hline $\mathrm{CH}_{4}(\mathrm{ppm})$ & $9.56 \pm 4$ & $22.5 \pm 11$ & - & - & - \\
\hline $\mathrm{He}(\mathrm{ppm})$ & $4.66 \pm 0.3$ & $3.55 \pm 0.8$ & - & - & - \\
\hline$\delta \mathrm{C}^{13}(\%)$ & $-3.29 \pm 0.8$ & $-4.25 \pm 0.5$ & -8.50 & - & - \\
\hline$\delta \mathrm{O}^{18}(\%)$ & - & - & - & $-17.4 \pm 1.7$ & -15.6 \\
\hline$\delta \mathrm{D}(\%)$ & - & - & - & $-82.2 \pm 30$ & -114 \\
\hline $\mathrm{CO}_{2} / \mathrm{CO}$ & $1.37 \pm 0.68$ & $0.502 \pm 0.15$ & - & - & - \\
\hline $\mathrm{CO}_{2} / \mathrm{CH}_{4}$ & $0.315 \pm 0.05$ & $0.288 \pm 0.16$ & - & - & - \\
\hline $\mathrm{CO}_{2} / \mathrm{H}_{2}$ & b.d.l. & $1.77 \pm 0.14$ & - & - & - \\
\hline
\end{tabular}

the isotopic composition is considered to be representative of the Hekla emissions.

\subsubsection{Analytical procedures}

The condensate samples were analysed for $\delta \mathrm{D}$ and $\delta^{18} \mathrm{O}$ on a Delta V Advantage mass spectrometer at the Institute for Earth Sciences at the University of Iceland. For comparison with the background environmental levels, we analysed $\delta \mathrm{D}$ and $\delta^{18} \mathrm{O}$ in freshly fallen snow (less than 3-4 days old) collected near the summit where there were no manifestations of elevated heat or gas emissions.

The dry gas samples were analysed for composition and $\delta^{13} \mathrm{C}\left(\mathrm{CO}_{2}\right)$ at the Istituto Nazionale di Geofisica e Vulcanologia (INGV) in Palermo. Concentrations of $\mathrm{He}$, $\mathrm{O}_{2}, \mathrm{~N}_{2}, \mathrm{CO}_{2}, \mathrm{CO}$ and $\mathrm{CH}_{4}$ were determined by a Perkin Elmer Auto system XL gas chromatograph, equipped with Carboxen 1000 columns, HWD and FID detectors, and using argon as carrier. Uncertainty is $\sim 5 \%$ of measured values. Carbon isotope composition of $\mathrm{CO}_{2}$ (and $\mathrm{CO}_{2}$ concentration) was determined by using a Thermo Delta Plus XP CF-IRMS, coupled with a Thermo TRACE Gas Chromatograph (GC) and a Thermo GC/C III interface. The TRACE GC is equipped with a Poraplot $\mathrm{Q}^{\circledR}$ $(0.32 \mathrm{~mm} \times 25 \mathrm{~m})$ column and uses Helium (N5.6) as carrier gas at a constant flow of $0.9 \mathrm{cc} / \mathrm{min}$. Undesired gas species, such as $\mathrm{N}_{2}, \mathrm{O}_{2}$, and $\mathrm{CH}_{4}$, are vented to atmosphere by means of back-flush of $\mathrm{He}$ and a Sige valve. Typical analytical precision and reproducibility $(1 \sigma)$ of $\delta^{13} \mathrm{C}\left(\mathrm{CO}_{2}\right)$ measurements are better than 0.2 and $0.3 \%$ respectively. The results are summarized in Table 2 and full analysis results are included in Appendix I.

\subsection{Reaction path modelling}

Reaction path modelling was used to test if the measured composition of Hekla surface gas emissions is consistent with that of a residual gas formed after scrubbing of (water-soluble) reactive species from an initial deeplyoriginated magmatic gas, operated by infiltrated groundwater (Fig. 4). We used the reaction path modelling approach of Helgeson (1968) and Helgeson et al. (1969) to numerically simulate interactions in the gas-water-rock system.

Reaction path simulations were performed with the EQ3/6 software package (7.2 version; Wolery, 1992; Wolery and Daveler, 1992). This code, initially designed to model water-rock interactions in shallow (e.g., sedimentary) environments (Helgeson, 1968, 1979; Helgeson et al., 1969; Gislason and Eugster, 1987), was subsequently extended to more extreme conditions, such as to model hydrothermal reactions (Giggenbach, 1988; Hedenquist and Lowenstern, 1994).

Marini and Gambardella (2005) and Di Napoli et al. (2014) were the first to apply EQ3/6 to studying magmatic gas scrubbing, although in simple (gas + pure water) conditions. Following the original work of Marini and Gambardella (2005), we simulated here scrubbing as a process of step-wise addition of increasing quantities of an high-temperature magmatic gas phase to an initial, low salinity, water.

\subsubsection{Initialization of the model}

Four sets of model runs were carried out ( 20 simulations in total; Table 3). All runs were initialized with an identical initial aqueous solution: a cold $\left(T=4.1^{\circ} \mathrm{C}\right)$, neutral ( $\mathrm{pH}=7.7$ ) and low-salinity (Total Dissolved Solids, TDS $=300 \mathrm{mg} / \mathrm{l}$ ) spring water emerging to the north-west of Hekla volcano (sample RB1E; Holm et al., 2010) was selected as a proxy for infiltrating waters, and was thus used as the starting point of the simulations. Each run was isobaric and isothermal: pressure was $0.1 \mathrm{MPa}$ in all runs (to explore scrubbing at near-surface, groundwater 


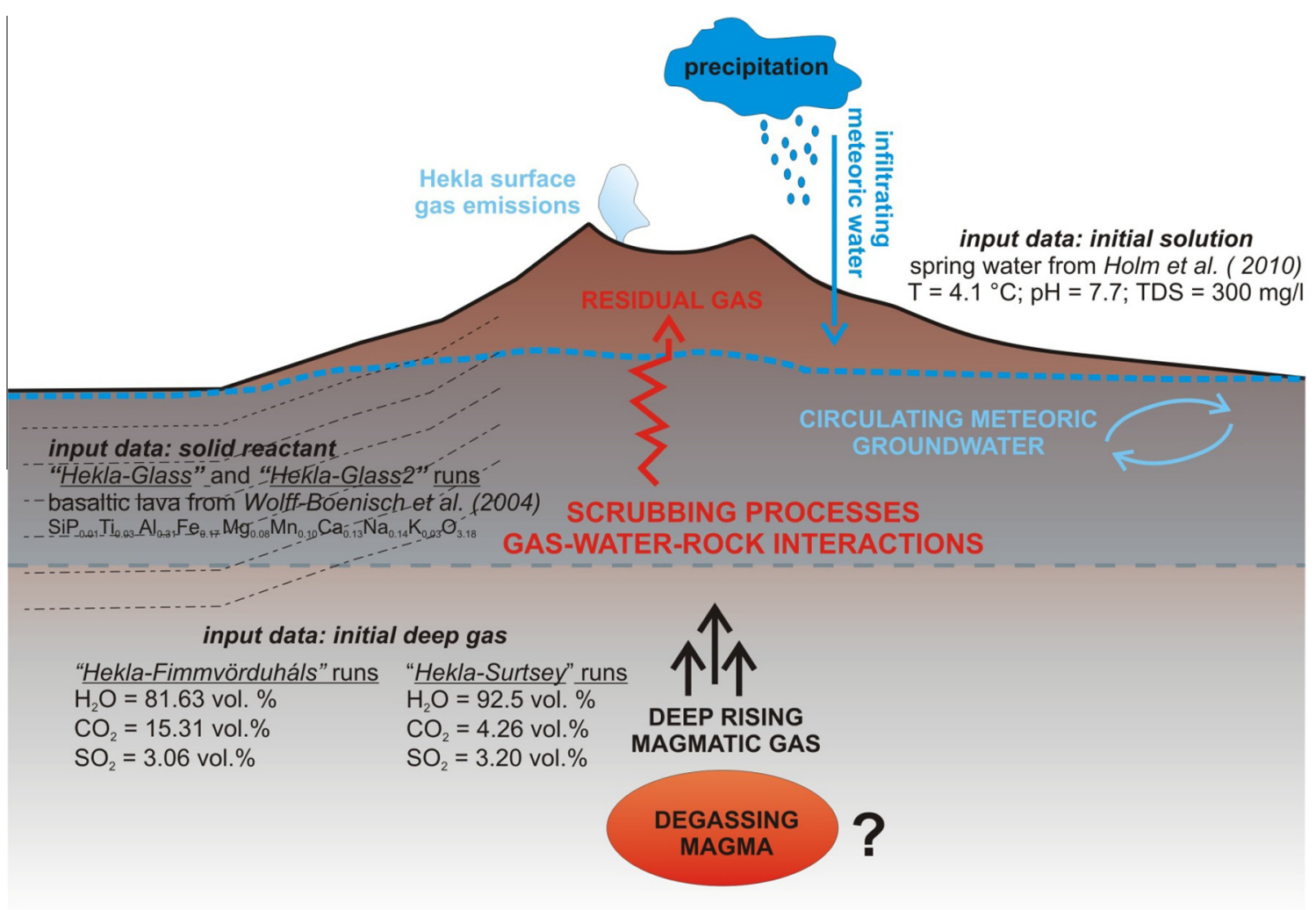

Fig. 4. A schematic cartoon of the gas-water-rock interaction model used, with indication of the parameters used to initialise the calculations.

Table 3

Summary of parameters used in the reaction path model. Four model runs were carried out ${ }^{(*)}$ normalised to solid reactant reaction rate; ${ }^{(1)}$ Holm et al. (2010); ${ }^{(2)}$ Burton et al. (2010); ${ }^{(3)}$ Gerlach (1980); ${ }^{(4)}$ Sigvaldason and Elisson (1968); ${ }^{(5)}$ Wolff-Boenisch et al. (2004).

\begin{tabular}{|c|c|c|c|c|c|c|c|}
\hline Model run & $\begin{array}{l}T \\
\left({ }^{\circ} \mathrm{C}\right)\end{array}$ & $\begin{array}{l}\text { Initial aqueous } \\
\text { solution }\end{array}$ & Initial deep gas & $\begin{array}{l}\text { Total gas } \\
\text { added } \\
(\mathrm{mol})\end{array}$ & Solid reactant & $\begin{array}{l}\text { Mol of } \\
\text { solid } \\
\text { reactant }\end{array}$ & $\begin{array}{l}\text { Relative } \\
\text { gas dissolution } \\
\text { rate }^{(*)}\end{array}$ \\
\hline $\begin{array}{l}\text { Hekla- } \\
\text { Fimmvörduháls }\end{array}$ & $14-98$ & Sample RB1E ${ }^{(1)}$ & $\begin{array}{l}\text { Fimmvörduháls } \\
\text { gas }^{(2)}\end{array}$ & 5.4 & None & - & - \\
\hline Hekla-Surtsey & 30-99 & Sample RB1E ${ }^{(1)}$ & Surtsey gas ${ }^{(3 ; 4)}$ & 5.3 & None & - & - \\
\hline Hekla-Glass & $93-99$ & Sample RB1E ${ }^{(1)}$ & $\begin{array}{l}\text { Fimmvörduháls } \\
\operatorname{gas}^{(2)}\end{array}$ & 5.5 & $\begin{array}{l}\text { Hydrated Hekla } \\
\text { Glass }^{(5)}\end{array}$ & 77.26 & 1 \\
\hline Hekla-Glass2 & $\begin{array}{l}14- \\
100\end{array}$ & Sample RB1E ${ }^{(1)}$ & $\begin{array}{l}\text { Fimmvörduháls } \\
\operatorname{gas}^{(2)}\end{array}$ & 6 & $\begin{array}{l}\text { Hydrated Hekla } \\
\text { Glass }\end{array}$ & 77.26 & 25 \\
\hline
\end{tabular}

conditions), while temperature varied from one run to another, and spanned from $\sim 7.5^{\circ} \mathrm{C}$ to just below boiling $\left(99.1^{\circ} \mathrm{C}\right)$ (see below).

The four sets of model runs differed by either (a) the composition of the interacting deep gas, or (b) for the presence or absence of solid (rock) reactants. The original composition of the deep gas feeding Hekla surface emissions is unknown and in the view of limited available information on high-temperature magmatic gases in Iceland, only very crude guesses can be made.

In the first set of runs (hereafter referred as HeklaFimmvörduháls runs; 13 simulations in total), we used - as proxy for the initial (pre-scrubbing) deep gas - the composition $\left(\mathrm{H}_{2} \mathrm{O}=81.63\right.$ vol. $\%, \quad \mathrm{CO}_{2}=15.31$ vol. $\%$, and $\mathrm{SO}_{2}=3.06$ vol. $\%$ ) of volcanic gases measured (by FTIR) during the Fimmvörduháls fissure eruption phase of Eyjafjallajökull in March 2010 (Burton et al., 2010). The second set of model runs (Hekla-Surtsey runs; $n=4$ ) were instead initialized using a more hydrous, less- $\mathrm{CO}_{2}$ rich initial gas $\left(\mathrm{H}_{2} \mathrm{O}=92.54 \%, \mathrm{CO}_{2}=4.26 \%\right.$, and $\mathrm{SO}_{2}=3.20 \%$ in vol), which was obtained by averaging available volcanic gas compositional data from the subaerial (nonphreatomagmatic) phase of the 1963-67 Surtsey eruption (Sigvaldason and Elisson, 1968; Gerlach, 1980). In both of these sets of model runs, no solid reactant (rock) was allowed to dissolve: any difference between their results therefore reflects the uncertainties due to poorly defined composition of the initial deep gas. However, in the third and fourth sets of model runs (Hekla-Glass and HeklaGlass 2 runs, $n=5$ ) we tested how the interaction with a 
solid reactant (see below) influences the model results (both Hekla-Glass runs used Fimmvörduháls composition as the initial deep gas).

In all four sets of simulations above, the temperature of the initial deep gas (before interaction with the initial solution) was set as $800^{\circ} \mathrm{C}$, to account for some cooling from an initial magmatic temperature of $>1100{ }^{\circ} \mathrm{C}$ (Sigvaldason and Elisson, 1968). The initial deep gas temperature determines the temperature of the model aqueous solution through a simple enthalpy balance. We estimate from our tests that increasing/decreasing the initial deep gas temperature by up to $200{ }^{\circ} \mathrm{C}$ leads to negligible variations on the model results.

All calculations were carried out using the thermodynamic database data0.com.R2 of EQ3/6, suitably modified by integrating the equilibrium constants (log K) for dissociation reactions of reactant gases (Fimmvörduháls gas and Surtsey gas), in the investigated $T\left(7.5-99.1^{\circ} \mathrm{C}\right)$ range and at $0.1 \mathrm{MPa}$ pressure. The equilibrium constants were calculated from $\log \mathrm{K}$ values of dissociation reactions of pure $\mathrm{H}_{2} \mathrm{O}, \mathrm{CO}_{2}$ and $\mathrm{SO}_{2}$ (taken from data0.com. R2).

By analogy with previous water-rock modelling work on Hekla (Flaathen et al., 2009), the solid reactant used in the Hekla-Glass runs was a basaltic glass, whose chemical composition $\left(\mathrm{Si} \mathrm{P}_{0.01} \mathrm{Ti}_{0.03} \mathrm{Al}_{0.31} \mathrm{Fe}_{0.17} \mathrm{Mg}_{0.08} \mathrm{Mn}_{0.10} \mathrm{Ca}_{0.13}\right.$ $\begin{array}{llll}\mathrm{Na}_{0.14} & \mathrm{~K}_{0.03} & \mathrm{O}_{3.18} & \\ \text {; Wolff-Boenisch et al., 2004) coincides }\end{array}$ with that of volcanics from the 2000 Hekla eruption (Moune et al., 2006, 2007). In view of recent theory (Oelkers et al., 1999; Oelkers, 2001; Gislason and Oelkers, 2003) that during water-rock interaction, only the hydrated surface layer of volcanic glass (enriched in Si and Al), and not the bulk glass, attains equilibrium with leaching solutions, we used the thermodynamic and kinetic properties of the Hydrated Hekla Glass $\left(\mathrm{SiAl}_{0.31} \mathrm{O}_{2}(\mathrm{OH})_{0.93}\right)$ of Wolff-Boenisch et al. (2004), which dissolution reaction is:

$\mathrm{SiAl}_{0.31} \mathrm{O}_{2}(\mathrm{OH})_{0.93} 0.93 \mathrm{H}^{+}+1.07 \mathrm{H}_{2} \mathrm{O}=\mathrm{H}_{4} \mathrm{SiO}_{4}+0.31 \mathrm{Al}^{3+}$

In the assumption that pore spaces of the solid reactant are water-saturated, we used an effective inter-granular porosity of 0.3 and a density of $2.79 \mathrm{~g} / \mathrm{cm}^{3}$ (WolffBoenisch et al., 2004) to calculate that $77.26 \mathrm{~mol}$ of Hydrated Hekla Glass interact with $1 \mathrm{~kg}$ of the initial aqueous solution. The dissolution rate of reaction (Eq. (1)) was regulated according to transition state theory-based rate law (Wolery and Daveler, 1992). We used a total surface area of $7.81 \cdot 10^{6} \mathrm{~cm}^{2}$ (from measured BET specific surface area; Wolff-Boenisch et al., 2004), and dissolution rate constant ( $\mathrm{rk}=8.56 \cdot 10^{-11} \mathrm{~mol} \mathrm{~cm} \mathrm{~s}^{-2} \mathrm{~s}^{-1}$ at $\left.25^{\circ} \mathrm{C}\right)$ and activation energy $\left(E_{\mathrm{A}}=25.5 \mathrm{~kJ} \mathrm{~mol}^{-1}\right.$ at $\left.25^{\circ} \mathrm{C}\right)$ from Gislason and Oelkers (2003). Those elements not included in Hydrated Hekla Glass formula were included in the EQ3/6 input file as a special reactant (Wolery and Daveler, 1992) referred as Hekla Glass Cations $\left(\mathrm{Fe}_{2} \mathrm{O}_{3}=0.03\right.$; $\mathrm{FeO}=0.11 ; \quad \mathrm{MgO}=0.08 ; \quad \mathrm{CaO}=0.13 ; \quad \mathrm{Na}_{2} \mathrm{O}=0.07 ;$ $\mathrm{K}_{2} \mathrm{O}=0.02$, all as molar fractions): a total of $77.26 \mathrm{~mol}$ (same as for the Hydrated Hekla Glass) of this special reactant were allowed to react with $1 \mathrm{~kg}$ of initial solution.

In the thirteen Hekla-Fimmvörduháls runs, different amounts (from 0.2 to $5.4 \mathrm{~mol}$ ) of the same Fimmvörduháls gas were added to $1 \mathrm{~kg}$ of the initial solution. At each step of addition, e.g. in each specific run, temperature was fixed by solving an enthalpy balance between the initial deep gas $\left(800^{\circ} \mathrm{C}\right)$ and the initial aqueous solution $\left(4.1^{\circ} \mathrm{C}\right)$. Fig. 5 shows that, as the molar amounts of added gas increased, the temperature consistently increased as well, from $7.5^{\circ} \mathrm{C}(0.2 \mathrm{~mol}$ added $)$ to $98.3^{\circ} \mathrm{C} \quad(5.4 \mathrm{~mol}$ added $)$. Varying the chemical composition of the initial deep gas had trivial influence on the temperature trend (compare results of Hekla-Fimmvörduháls runs and Hekla-Surtsey runs in Fig. 5).

The rate at which gas dissolves into water was originally taken as identical to dissolution rate of the solid reactant in the Hekla-Glass run. We then performed the fourth model run (Hekla Glass2 run), which is identical to Hekla-Glass but with a gas dissolution reaction rate being 25 times higher than the solid reactant rate.

During the model runs, each of the (differently) gasdoped solutions was allowed to equilibrate (at the specific run temperature) with a set of secondary minerals (quartz, smectite, saponite, calcite, pyrite), which were allowed to precipitate from model solutions upon reaching supersaturation. At the end of the run (e.g., after any available gas/solid reactant had completely dissolved into the initial solution), the equilibrium total gas pressure $\left(P_{\mathrm{g}, \mathrm{TOT}}\right)$ in the end-of-run aqueous solution was calculated by summing together the partial pressures of individual gas species (taken from the EQ6 output files). We obtained that, for the specific case of Hekla-Fimmvörduháls runs, gas over-saturation (e.g., $P_{\mathrm{g} \text {,тот }}$ exceeding $0.1 \mathrm{MPa}$ ) was realized from run 2 onward (e.g., for $>0.4 \mathrm{~mol}$ of gas was added). Three gases contributed, with their individual partial pressures $\left(p \mathrm{H}_{2} \mathrm{O}, p \mathrm{CO}_{2}\right.$ and $\left.p \mathrm{H}_{2} \mathrm{~S}\right)$ adding to $>99 \%$ of $P_{\mathrm{g}, \text { TOT }}$. Very similar results were obtained in the Hekla-Surtsey runs; whereas in the Hekla Glass runs gas over-saturation was obtained only for larger $(>5.1 \mathrm{~mol})$ additions of gas, reflecting the gas-neutralization role played by dissolution of the solid reactant.

For all end-of-run aqueous solutions in which gas oversaturation was observed, we applied a single-step degassing model (for details on the procedure, see Marini and Gambardella, 2005), according to the relation:

$\left(\frac{n_{j}}{n_{\mathrm{H}_{2} \mathrm{O}}}\right)_{\mathrm{g}}=\left(\frac{n_{j}}{n_{\mathrm{H}_{2} \mathrm{O}}}\right)_{\mathrm{o}} \times \frac{B_{j}}{1-f+f B_{j}}$

where $\left(\frac{n_{j}}{n_{\mathrm{H}_{2} \mathrm{O}}}\right)_{\mathrm{g}}$ is the molar fraction of the $j$ gas species in the separated gaseous phase; $\left(\frac{n_{j}}{n_{\mathrm{H}_{2} \mathrm{O}}}\right)_{\mathrm{o}}$ is the molar fraction of the $j$ gas species in the initial undegassed liquid; $B_{j}$ is equilibrium partition coefficient for the $j$ gas species and $f$ is the fraction of separated gaseous phase.

In brief, starting from the composition of each oversaturated end-of-run aqueous solution $\left(\left(\frac{n_{j}}{n_{\mathrm{H}_{2} \mathrm{O}}}\right)_{\mathrm{O}}\right.$ in Eq. (2); being either $\left(\mathrm{CO}_{2} / \mathrm{H}_{2} \mathrm{O}\right)_{0}$ or $\left(\mathrm{H}_{2} \mathrm{~S} / \mathrm{H}_{2} \mathrm{O}\right)_{\mathrm{o}}$ in our specific case; all extracted from the EQ6 output files), we calculated the compositions $\left(\frac{n_{j}}{n_{\mathrm{H}_{2} \mathrm{O}}}\right)_{\mathrm{g}}$ from Eq. (2); e.g., molar ratios of $\left(\mathrm{CO}_{2} / \mathrm{H}_{2} \mathrm{O}\right)_{\mathrm{g}}$ and $\left(\mathrm{H}_{2} \mathrm{~S} / \mathrm{H}_{2} \mathrm{O}\right)_{\mathrm{g}}$ of the gas phase separated upon increasing extents of degassing $(f$, the fraction of 
separated gas). In using Eq. (2), $f$ was step-wise increased (starting from $0=$ no degassing) until $P_{\mathrm{g}, \mathrm{TOT}}$ in the residual (degassed) aqueous solution decreased to $0.1 \mathrm{MPa}$ : that specific value of $f$ was used for calculating the composition of the separated gas. Furthermore, assuming equilibrium partitioning of each single gas $j$ between separating gas and the residual liquid, we calculated the equilibrium partition coefficient $\left(B_{j}\right)$ as the ratio between the Henry's solubility constant and the $\mathrm{H}_{2} \mathrm{O}$ saturation pressure, at the run temperature. The Henry's coefficients (for pure water) are from the data0.com.R2 database of EQ3/6.

\section{RESULTS}

\subsection{Ground temperature and $\mathrm{CO}_{2}$ flux}

Significantly elevated ground temperatures were discovered in two distinct areas: at the summit crater, and Öxl crater (Fig. 3). The $2012 T_{\mathrm{G}}$ measurements in these two areas were used to create a $T_{\mathrm{G}}$ map of each area. The summit area with elevated temperatures had a narrow, elongated shape, approximately $400 \times 75 \mathrm{~m}$ in size (Fig. 3). As the measurement grid at the summit was fairly dense $(10 \times 10 \mathrm{~m})$, the method of the inverse distance weighted (IDW) interpolation was used to create the map. The IDW is a linear-weighted interpolation which assigns values between two points on a linear scale thus creating contour lines. For the Öxl area (Fig. 3) the same interpolation was used although the grid was not complete. This is not considered to significantly impact our estimation of the total $\mathrm{CO}_{2}$ flux, as all $\varphi_{\mathrm{CO}_{2}}$ measurements in the Öxl area, including the points with the highest $T_{\mathrm{G}}$, were either below or just above the detection limit.

The measured $\varphi_{\mathrm{CO}_{2}}$ ranged from 0.12 to $23,000 \mathrm{~g} \mathrm{~m}^{-2}$ $\mathrm{d}^{-1}$ (Table 1). Sequential Gaussian simulation (sGs) method was used to process the $\varphi_{\mathrm{CO}_{2}}$ measurements. This method is commonly used to process results of $\varphi_{\mathrm{CO}_{2}}$ field surveys, e.g. Cardellini et al. (2003). The sGs method yields a given number of equiprobable realizations of the $\varphi_{\mathrm{CO}_{2}}$ in the surveyed area. In this case 100 realizations were obtained and the cell size used was $2 \times 2 \mathrm{~m}$. The results of the sGs allow quantification of the total $\varphi_{\mathrm{CO}_{2}}$ from the area, which is taken to be the average of the total $\varphi_{\mathrm{CO}_{2}}$ of all the 100 realizations as well as the standard deviation of those values, providing constraints on the uncertainty of the average total $\varphi_{\mathrm{CO}_{2}}$ for the field.

Fig. 3 shows the resulting modelled $\varphi_{\mathrm{CO}_{2}}$ in the surveyed area. The $\varphi_{\mathrm{CO}_{2}}$ shown for each cell in Fig. 3 represents the average value for that cell obtained in all the realizations. The total $\mathrm{CO}_{2}$ flux from the summit area was calculated to be $13.7 \pm 3.7 \mathrm{~T} \mathrm{~d}^{-1}$, where the uncertainty represents two standard deviations. This uncertainty is similar to the fluctuation revealed by repeated measurements at a selected reference point each day that data were collected $( \pm 17.5 \%)$.

The data collected in 2013 were too few to allow modelling and calculation of the total $\mathrm{CO}_{2}$ flux in the summit area. However, meaningful comparison can still be made between the two years, as the 2013 measurement locations coincide with the locations where the highest $\varphi_{\mathrm{CO}_{2}}$ values

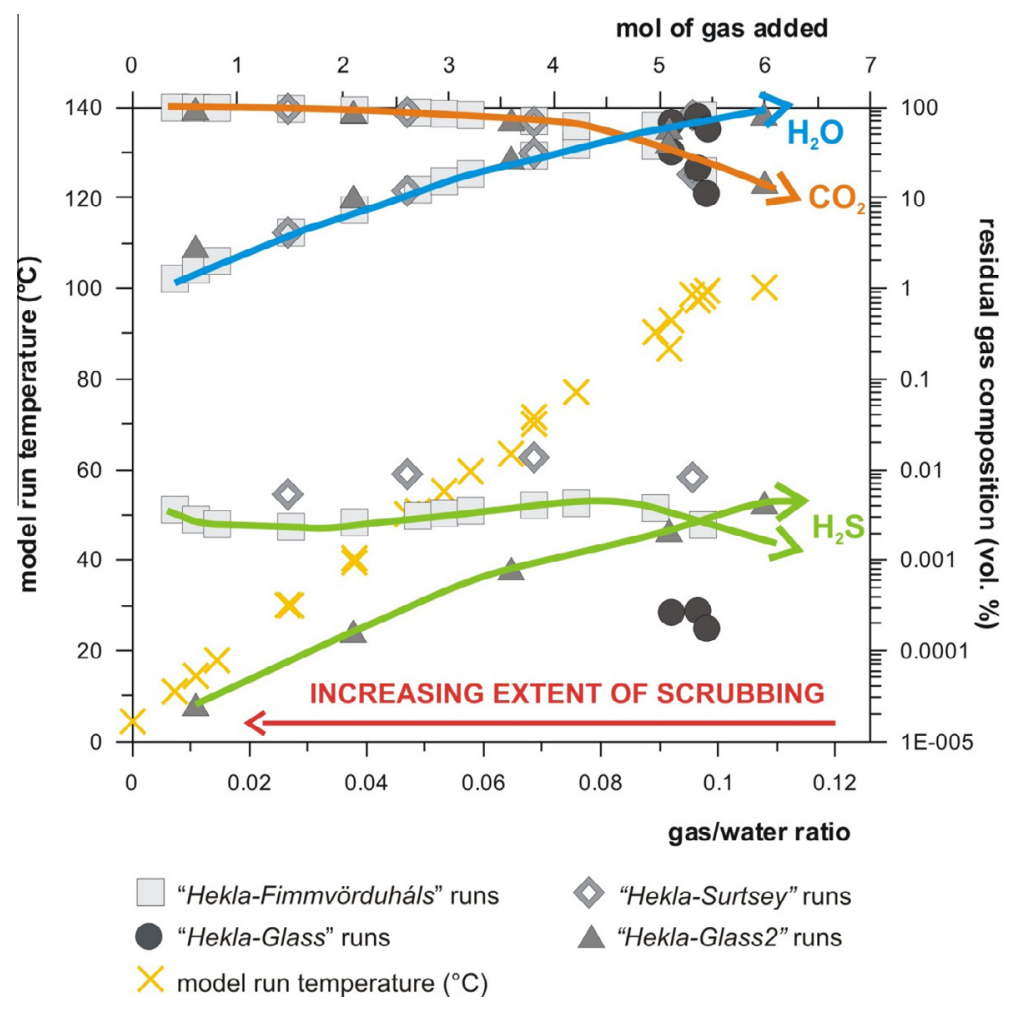

Fig. 5. Calculated (Eq. (2)) compositions $\left(\mathrm{CO}_{2}, \mathrm{H}_{2} \mathrm{O}\right.$ and $\mathrm{H}_{2} \mathrm{~S}$ concentrations, in vol \%) of the gas phase separated from each over-saturated $\left(P_{\mathrm{g}, \text { TOT }}>0.1 \mathrm{MPa}\right)$ end-of-run aqueous solution. The temperature of each model run (calculated from an enthalpy balance) is also shown. See text for description. 
were measured in 2012. Fig. 6 compares values of $T_{\mathrm{G}}$ and $\varphi_{\mathrm{CO}_{2}}$ which were measured in the same points in 2012 and $2013( \pm 5 \mathrm{~m})$. The difference in $T_{\mathrm{G}}$ values between the two years was small (mean $T_{\mathrm{G}}$ value difference $<1{ }^{\circ} \mathrm{C}$; Table 1) and is not considered significant. There was more variability in $\varphi_{\mathrm{CO}_{2}}$ point values between 2012 and 2013 (mean $\varphi_{\mathrm{CO}_{2}}$ point values of 4000 and $5600 \mathrm{~g} \mathrm{~m}^{-2}$ day $^{-1}$, respectively) but all point values are comparable to within one degree of magnitude. Larger differences in $\varphi_{\mathrm{CO}_{2}}$ occurred near both ends of the profile $(125-215 \mathrm{~m})$, with higher values in 2013. We do not have enough data to quantify the difference in the total gas flux between the two years, but some increase in total $\mathrm{CO}_{2}$ flux cannot be excluded. The difference in total $\mathrm{CO}_{2}$ flux between the two years may be attributed to several possible reasons: (i) a change in volcanic gas flux from depth, (ii) shift in the location of the high-gas emission area (due to fluctuations in the degassing pathway and/or more extensive seasonal snow cover in 2013), (iii) slight difference in the measurement location.

It is important to estimate $\varphi_{\mathrm{CO}_{2}}$ from unmapped areas. We calculated $\varphi_{\mathrm{CO}_{2}}$ based on the following evidence: (i) We have identified all of the areas where the $T_{\mathrm{G}}$ and $\varphi_{\mathrm{CO}_{2}}$ are significant. This is based on visual observations (manifestations of elevated $T_{\mathrm{G}}$, such as absence of snow cover, non-frozen ground, and steam emanations). (ii) Mean $\varphi_{\mathrm{CO}_{2}}$ in 'cold' soil areas was $\sim 13 \mathrm{~g} \mathrm{~m}^{-2} \mathrm{~d}^{-1}$, while the mean $\varphi_{\mathrm{CO}_{2}}$ at the summit was $\sim 4000 \mathrm{~g} \mathrm{~m}^{-2} \mathrm{~d}^{-1}$ (Table 1). Based on this, we can estimate that the average summit $\varphi_{\mathrm{CO}_{2}}$ is $\sim 300$ times higher than the average $\varphi_{\mathrm{CO}_{2}}$ elsewhere on the mountain. (iii) The unmapped area is $\sim 670$ times larger than the mapped area at the summit. (iv) Combining this evidence, we calculate that the $\mathrm{CO}_{2}$ flux from the unmapped areas is at least $30 \mathrm{~T} \mathrm{~d}^{-1}$, i.e. approximately twice as large as the emissions from the summit area. The total $\varphi_{\mathrm{CO}_{2}}$ from Hekla central volcano is therefore estimated as at least $43.7 \mathrm{~T} \mathrm{~d}^{-1}$.

\subsection{Gas composition}

Analysis of dry gas samples showed that Hekla's emissions are significantly mixed with background air by the time they reach the surface, containing on average $76.6 \%$ $\mathrm{N}_{2}$ and $18.9 \% \mathrm{O}_{2}$ in 2012 and $74.4 \% \mathrm{~N}_{2}$ and $19.1 \% \mathrm{O}_{2}$ in 2013 (Table 2). This is likely explained by the permeability of the poorly compacted top tephra layers. However, concentrations of $\mathrm{CO}_{2}, \mathrm{CO}, \mathrm{CH}_{4}$ and $\mathrm{H}_{2}$ were noticeably elevated above known background level, especially in 2013 which is believed to be due to a better sampling technique. Ratios between the 'volcanic' gas species are shown in Table 2. There is no significant difference between 2012 and 2013 based on the standard deviation of the two sample sets.

Analysis of MultiGAS data (see Appendix II for full results) was performed using RatioCalc v1.5 and 2.0 software, which allows for automatic creation of gas species scatter plots from data acquired within any single $30 \mathrm{~min}$
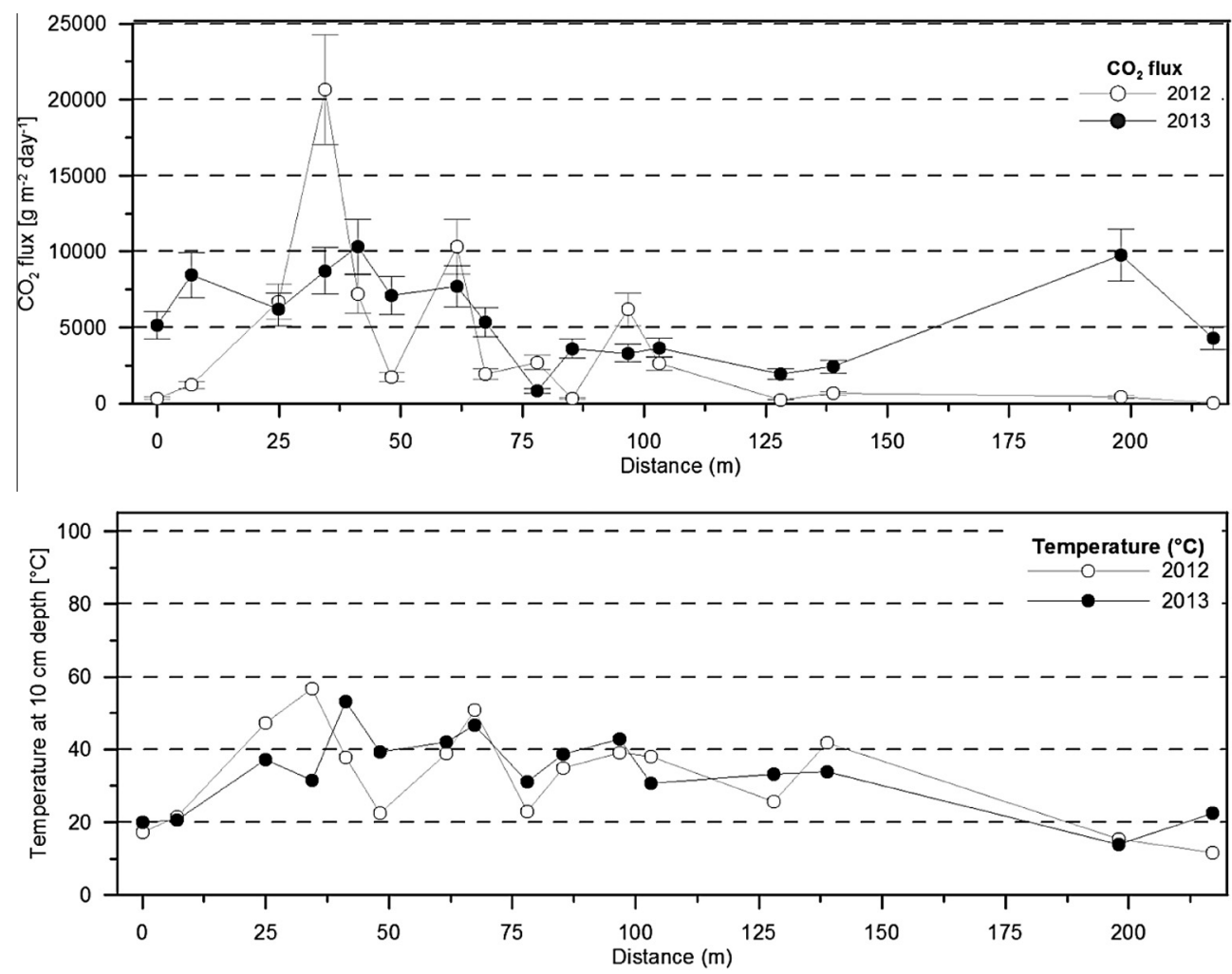

Fig. 6. Comparison of ground temperature ( $\left.T_{\mathrm{G}}\right)$ and diffuse $\mathrm{CO}_{2}$ soil flux in 2012 and 2013 as measured along the longitudinal axis of Hekla's summit (measured from SW to NE). The error bars for the $\mathrm{CO}_{2}$ flux [top diagram] are based on repeated measurements of a reference point. The uncertainty of the thermometer used for $T_{\mathrm{G}}$ measurements [bottom diagram] is $\pm 0.5^{\circ} \mathrm{C}$ and falls within the plot symbols. 
measurement cycle, and calculation of gas species ratios from the gradient of best-fit regression lines through the data scatter (same methodology as Aiuppa et al., 2009, 2010). Examples of scatter plots are given in Appendix III. Calculations were restricted to measurement intervals when measured concentrations showed substantial excess relative to ambient air (e.g., when $\mathrm{CO}_{2}$ was $>16$ ppm above ambient air, see Appendix II). Given the relatively low flux of the diffuse Hekla emissions and high degree of mixing with ambient air, this condition was fulfilled in only $\sim 30 \%$ of 2012 measurement cycles. $\mathrm{H}_{2} \mathrm{O} / \mathrm{CO}_{2}$ and $\mathrm{CO}_{2} /$ $\mathrm{H}_{2} \mathrm{~S}$ ratios used for data interpretation had an $R^{2}$ value of $>0.5$.

Fig. 7 shows the variations in maximum $\mathrm{CO}_{2}$ concentrations and the $\mathrm{H}_{2} \mathrm{O} / \mathrm{CO}_{2}$ ratio in $2012(0.1-7.2$, with a mean value of $1.6 \pm 1.6$ at $1 \sigma)$. The spread of $\mathrm{H}_{2} \mathrm{O} / \mathrm{CO}_{2}$ ratios is larger at low gas concentrations (e.g., for $\mathrm{CO}_{2 \text {,excess }}<100$ ppm; $\mathrm{CO}_{2 \text {,excess }}$ stands for ambient air-subtracted MultiGAS concentrations). In such conditions, the retrieval algorithm in RatioCalc finds the volcanic signal more difficult to distinguish from the dominating atmospheric signal. This is supported by correlating the prevailing wind speed and gas concentrations. Higher gas concentrations were detected during periods with lower wind speed (Fig. 7), when volcanic gas is diluted to a lesser degree by ambient air. On the other hand, in more concentrated volcanic gas the range of derived $\mathrm{H}_{2} \mathrm{O} / \mathrm{CO}_{2}$ ratios becomes narrower (0.2-2.9 for samples with $\left.\mathrm{CO}_{2 \text {,excess }}>1000 \mathrm{ppm}\right)$. Therefore, we consider this range more representative of the 'volcanic' gas signature.

In 2013, the concentrations of $\mathrm{CO}_{2}$ have been consistently close to, or above, $1000 \mathrm{ppm}$ (full results in Appendix II). This is most likely due to the new station set-up where the inlet takes in gas directly from the soil allowing less mixing with background air than in the setup of 2012. The derived $\mathrm{H}_{2} \mathrm{O} / \mathrm{CO}_{2}$ ratios with
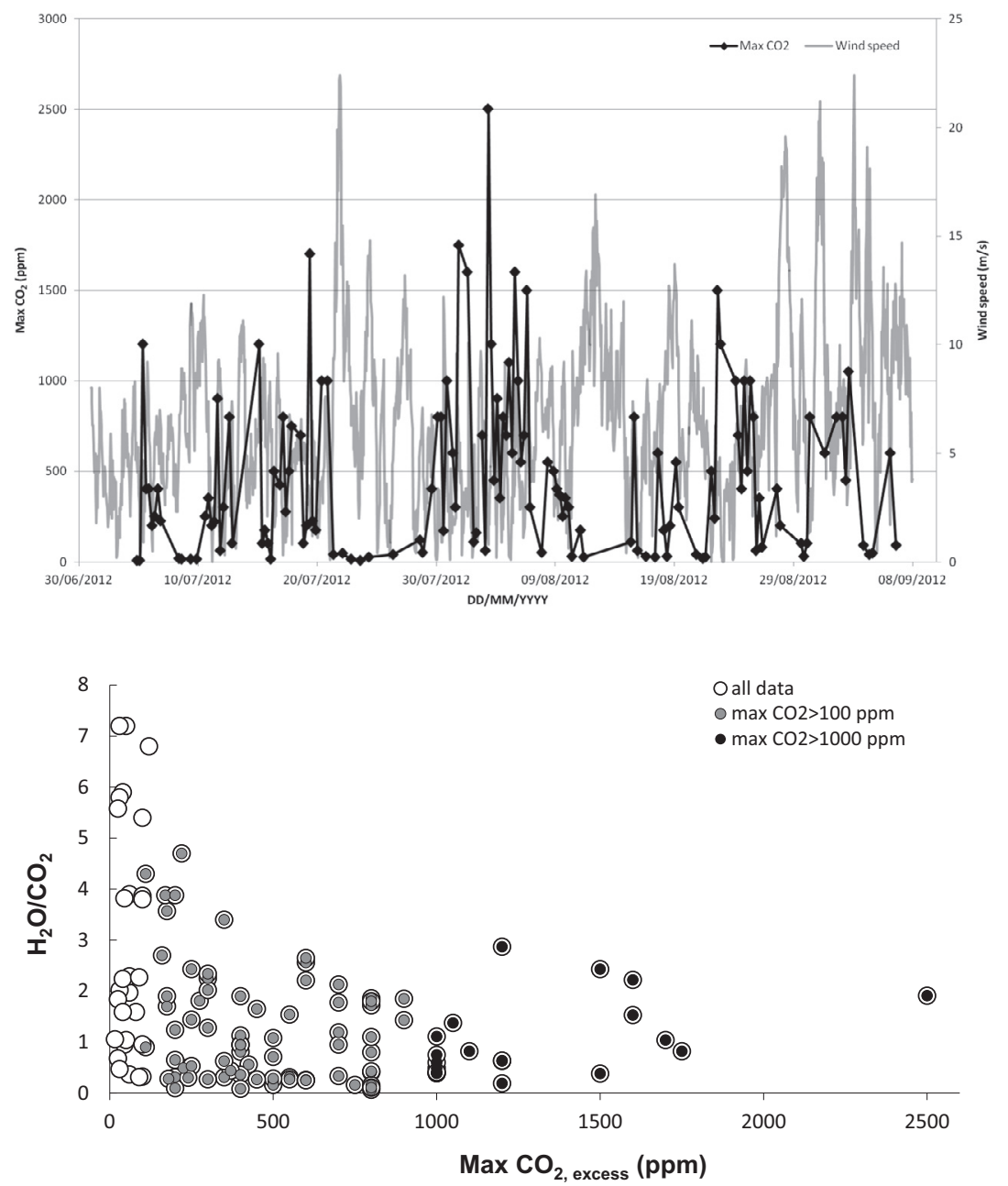

Fig. 7. Variations in maximum $\mathrm{CO}_{2}$ concentration in 2012 as a function of prevailing wind speed [top diagram] and related variations in the $\mathrm{H}_{2} \mathrm{O} / \mathrm{CO}_{2}$ ratio [bottom diagram]. The wind speed $(\mathrm{m} / \mathrm{s})$ is represented by one-hour average value, measured at Vatnsfell station $\left(64.20^{\circ} \mathrm{N}\right.$ $19.05^{\circ} \mathrm{W}, 540 \mathrm{~m}$ a.s.l.). The station is located $45 \mathrm{~km}$ to the $\mathrm{NE}$ of Hekla, and is the nearest weather station with the most similar altitude. The figure illustrates that high $\mathrm{CO}_{2}$ values were generally measured during intervals of lower wind speed. The spread of $\mathrm{H}_{2} \mathrm{O} / \mathrm{CO}_{2} \mathrm{ratios}$ is greatest at low gas concentrations (e.g., for $\mathrm{CO}_{2 \text {,excess }}<100 \mathrm{ppm}$ ). The range of $\mathrm{H}_{2} \mathrm{O} / \mathrm{CO}_{2}$ ratios becomes narrower in more concentrated gas $(0.2-2.9$ for $\mathrm{CO}_{2 \text {,excess }}>1000 \mathrm{ppm}$ ) and it is considered to be more representative of the 'volcanic' gas signature. 
Table 4

Summary of $\mathrm{H}_{2} \mathrm{O} / \mathrm{CO}_{2}$ and $\mathrm{CO}_{2} / \mathrm{H}_{2} \mathrm{~S}$ molar ratios as measured by MultiGAS station in 2012 and 2013, including the mean $(\mu)$ and standard deviation $(1 \sigma)$. The more concentrated gas $\left(\mathrm{CO}_{2, \text { excess }}>1000 \mathrm{ppm}\right)$ is considered to be more representative of Hekla's gas signature.

\begin{tabular}{|c|c|c|c|c|}
\hline \multirow[t]{2}{*}{ Molar ratio } & \multicolumn{2}{|l|}{2012} & \multicolumn{2}{|l|}{2013} \\
\hline & $\operatorname{Min}-\max$ & $\mu \pm 1 \sigma$ & $\operatorname{Min}-\max$ & $\mu \pm 1 \sigma$ \\
\hline $\mathrm{H}_{2} \mathrm{O} / \mathrm{CO}_{2}$ & $0.07-7.2$ & $1.6 \pm 1.6$ & $0.01-5.8$ & $0.41 \pm 0.72$ \\
\hline $\mathrm{H}_{2} \mathrm{O} / \mathrm{CO}_{2}\left(\mathrm{CO}_{2, \text { excess }}>1000\right)$ & $0.2-2.9$ & $1.3 \pm 0.84$ & $0.01-3.1$ & $0.30 \pm 0.45$ \\
\hline $\mathrm{CO}_{2} / \mathrm{H}_{2} \mathrm{~S}$ & $0.22 \times 10^{3}-3.3 \times 10^{4}$ & $7.8 \times 10^{3} \pm 8.6 \times 10^{3}$ & $4.0 \times 10^{3}-3.2 \times 10^{5}$ & $8.9 \times 10^{4} \pm 7.0 \times 10^{4}$ \\
\hline $\mathrm{CO}_{2} / \mathrm{H}_{2} \mathrm{~S}\left(\mathrm{CO}_{2, \text { excess }}>1000\right)$ & $3.5 \times 10^{3}-3.3 \times 10^{4}$ & $1.5 \times 10^{4} \pm 1.1 \times 10^{4}$ & Same as above & Same as above \\
\hline $\mathrm{H}_{2} \mathrm{O} \mathrm{mol} \%$ & $0.14-0.88$ & $0.57 \pm 0.21$ & $0.03-0.8$ & $0.21 \pm 0.14$ \\
\hline $\mathrm{CO}_{2} \mathrm{~mol} \%$ & $0.12-0.86$ & $0.43 \pm 0.21$ & $0.2-0.97$ & $0.79 \pm 0.14$ \\
\hline $\mathrm{H}_{2} \mathrm{~S} \mathrm{~mol} \%$ & $1.5 \times 10^{-5}-1.1 \times 10^{-3}$ & $1.9 \times 10^{-4} \pm 2.3 \times 10^{-4}$ & $3.0 \times 10^{-6}-4.8 \times 10^{-5}$ & $8.0 \times 10^{-6} \pm 3.4 \times 10^{-6}$ \\
\hline
\end{tabular}

$\mathrm{CO}_{2 \text {,excess }}>1000 \mathrm{ppm}$ range between 0.01 and 3.1 , are therefore very similar to 2012 (Table 4).

The sub-population of $\mathrm{CO}_{2 \text {,excess }}>1000$ data shows a mean $\mathrm{H}_{2} \mathrm{O} / \mathrm{CO}_{2}$ ratio of 1.3 in 2012 , and 0.30 in 2013 (Table 4). While we cannot exclude that there has been a change in the emitted gas composition between 2012 and 2013 (see Section 3.1 on total $\mathrm{CO}_{2}$ flux), we believe that the lower $\mathrm{H}_{2} \mathrm{O} / \mathrm{CO}_{2}$ ratio in 2013 is most likely caused by the difference in the sampling set-up. The emissions in 2013 are less diluted by background air and therefore believed to be more representative of the 'volcanic' gas composition at Hekla.
The Hekla gas is also found to be very sulphur-poor. We measured peak $\mathrm{H}_{2} \mathrm{~S}$ concentrations of only 400 and $450 \mathrm{ppb}$ (2012 and 2013, respectively), and most of our detections actually fall in the tens of $\mathrm{ppb}$ range, where the MultiGAS becomes increasingly inaccurate (full results in Appendix II). The very low $\mathrm{H}_{2} \mathrm{~S}$ concentrations, and the consequent large associated errors $(>50 \%$, compared to $<<20 \%$ in the ppm range), is sufficient to explain the high variability of $\mathrm{CO}_{2} / \mathrm{H}_{2} \mathrm{~S}$ ratios $(220-33,000$ and 4000 320,000 in 2012 and 2013, respectively; Table 4). The $\mathrm{H}_{2} \mathrm{O}$-poorest and $\mathrm{CO}_{2}$-richest data-points also show the most $\mathrm{H}_{2} \mathrm{~S}$-poor compositions (Fig. 8), with the

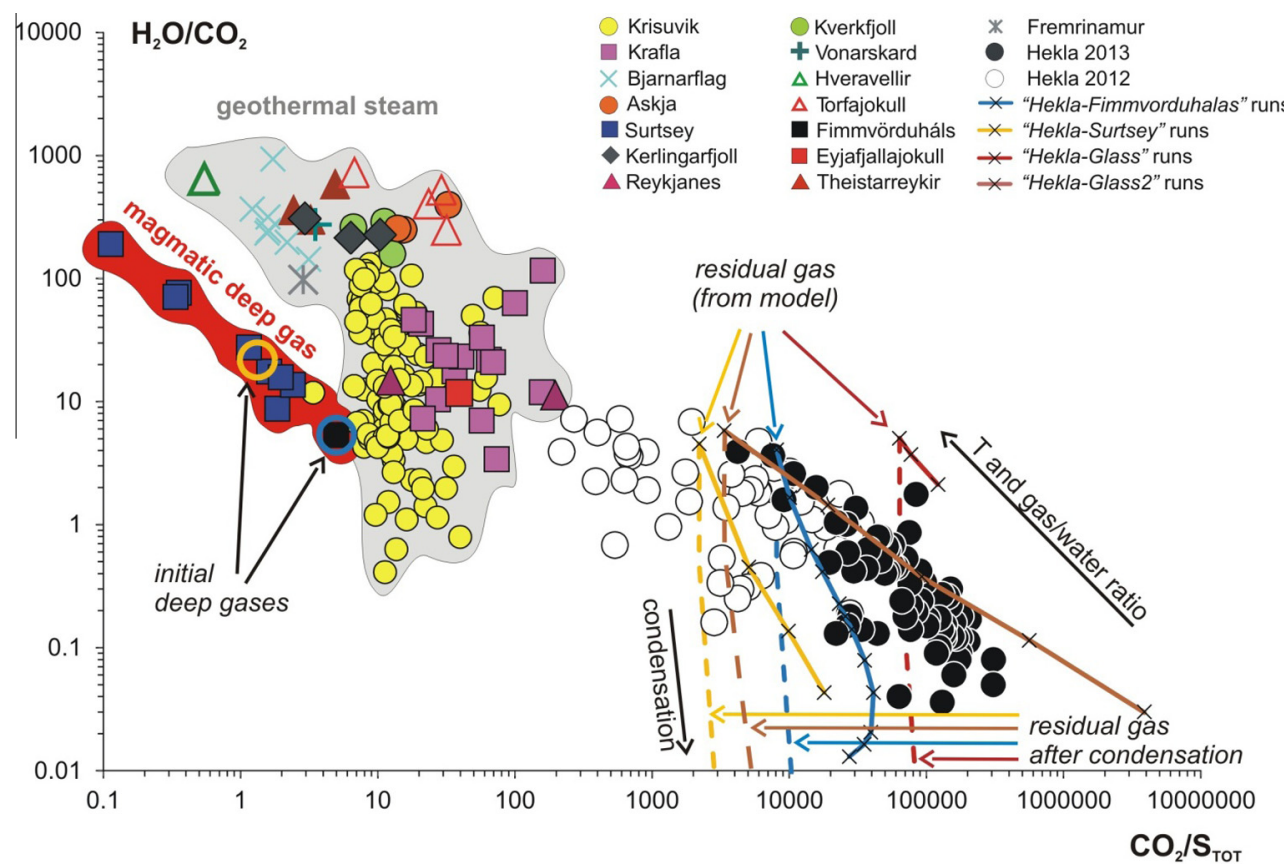

Fig. 8. Variation of $\mathrm{H}_{2} \mathrm{O} / \mathrm{CO}_{2}$ and $\mathrm{CO}_{2} / \mathrm{S}_{\mathrm{TOT}}$ molar ratios across different volcanic systems in Iceland. Total sulphur ( $\mathrm{S}_{\mathrm{TOT}}$ ) was calculated as the sum of $\mathrm{H}_{2} \mathrm{~S}_{\mathrm{g}}$ and $\mathrm{SO}_{2}$, where $\mathrm{SO}_{2}$ was detected. For our Hekla data (2012-2013), sulphur was found only as $\mathrm{H}_{2} \mathrm{~S}$. Gas emissions from Hekla 2012-2013 are typically S- and $\mathrm{H}_{2} \mathrm{O}$-depleted relative to Icelandic magmatic gases (Surtsey - Sigvaldason and Elisson, 1968, Gerlach, 1980. Fimmvörduháls - Burton et al., 2010. Eyjafjallajökull (intraglacial summit eruption - Allard et al., 2010), and relative to steam samples from volcanoes with highly active geothermal systems (Krísuvík - Icelandic Meteorological Office, monitoring data. Kverkfjöll, Krafla, Theistareykir, Bjarnarflag, Fremrinamur, Askja, Vonarskard, Hveravellir, Kerlingarfjöll, Torfajökull, Reykjanes - Oskarsson, 1984). The steam samples from geothermal sites around Iceland occupy an intermediate position between magmatic and Hekla-type gases. The figure also shows the compositions of model residual gases (solid lines), calculated from equation (2) (same data as in Fig. 5). The model residual gases overlap with the compositional field of Hekla gas emissions, indicating that they could be derived from magmatic gases through $\mathrm{S}$ - and $\mathrm{H}_{2} \mathrm{O}$ scrubbing. The dashed lines are indicative of the model evolution of residual gas compositions, after allowing for some extent of condensation (increasing from top to bottom) in the soil (the condensation curves were obtained after Chiodini and Marini, 1998). 
$\mathrm{CO}_{2, \text { excess }}>1000$ subset of samples having a mean $\mathrm{CO}_{2} /$ $\mathrm{H}_{2} \mathrm{~S}$ ratio of 15,000 and 89,000 in 2012 and 2013, respectively (Table 4). Hydrogen was very occasionally detected (measured in 2012 only), and was also characterized by very low concentrations (1.5-4 times as much abundant as $\mathrm{H}_{2} \mathrm{~S}$ ); while $\mathrm{SO}_{2}$ was systematically below $50 \mathrm{ppb}$ detection limit.

From the ratios above, we recalculated the molar compositions of Hekla gas (after removing the signal of ambient air), summarized in Table 4. The Hekla gas is found to be very $\mathrm{CO}_{2}$-rich (molar fractions of $0.2-0.98$ in 2013) and S-poor $\left(8.0 \times 10^{-6} \pm 3.4 \times 10^{-6}\right.$ in 2013), with $\mathrm{H}_{2} \mathrm{O}$ molar fractions of $0.03-0.80$. From the subset of samples with $\mathrm{CO}_{2 \text {,excess }}>1000 \mathrm{ppm}$, we obtain a best-guess of Hekla's volcanic gas of $0.21 \quad \mathrm{H}_{2} \mathrm{O}, \quad 0.79 \quad \mathrm{CO}_{2}$ and $8.0 \times 10^{-6} \mathrm{H}_{2} \mathrm{~S}$ molar fraction (as measured in 2013). Full list of obtained molar fractions is given in the Supplementary material (Appendix IV).

\subsection{Isotopic composition}

Carbon isotope composition $\left(\delta^{13} \mathrm{C}\right.$ in $\%$ relative to the PDB standard) of $\mathrm{CO}_{2}$ varied from -2.2 to $-5.4 \%$ with the exception of one sample with a very low value of $-19.7 \%$ (summary in Table 2; full results in Appendix I). Excluding the very low outlier, all the samples result from mixing of volcanic emissions and air in varying proportions (Fig. 9). The mean isotopic composition computed of the samples less affected by air-contamination $\left(\mathrm{CO}_{2}>5000 \mathrm{ppm}\right)$ is $-4.0 \pm 0.6 \%$ at $1 \sigma$ is consistent with the $\delta^{13} \mathrm{C}$ value that has been deduced for primitive Icelandic magmas $(-4.1 \pm 0.9 \%$, Marty et al., 1991; $-3.8 \pm 0.7 \%$, Poreda et al., 1992).



Fig. 9. Isotopic composition of $\delta^{13} \mathrm{C}$ of $\mathrm{CO}_{2}$ measured in dry gas samples from Hekla, and in ambient air for comparison. Only 5 samples were obtained in 2012 due to difficult sampling conditions ('Hekla gas 2012', one sample has been excluded from the plot as erroneous). Sampling was repeated in 2013 ('Hekla gas 2013'). There is no significant difference in $\delta^{13} \mathrm{C}$ between 2012 and 2013. The mean $\delta^{13} \mathrm{C}$ value, computed on combined results from both years and considering only the samples $(n=24)$ with $\mathrm{CO}_{2}$ contents higher than $5000 \mathrm{ppm}$ is $-4.0 \pm 0.6 \%$ o (at $1 \sigma$ ). The dashed lines show the range of values calculated for primitive Icelandic magmas $(-4.1 \pm 0.9 \%$, Marty et al., $1991 ;-3.8 \pm 0.7 \%$, Poreda et al., 1992).
The water isotopes ( $\delta \mathrm{D}$ and $\delta^{18} \mathrm{O}$ ) measured in a sample of fresh snow collected at an elevation of about $1430 \mathrm{~m}$ a.s. on the slopes of Hekla, are consistent with the global meteoric water line (GMWL, Craig, 1961) and are therefore believed to be representative of the local meteoric precipitation at that elevation (Fig. 10). Groundwater in the plains surrounding Hekla is also known to be isotopically consistent with GMWL, which further supports its meteoric origin, although not entirely local; springs west and southwest of Hekla have $\delta \mathrm{D}-60$ to $-70 \%$ and are believed to discharge local meteoric water, but springs north of Hekla have $\delta \mathrm{D}-73$ to $-77 \%$ indicating a source far to the northeast (Árnason, 1976; Gislason et al., 1992; Flaathen et al., 2009). The difference in deuterium content between the Hekla snow sample and spring water in the plains southwest of Hekla is $50-60 \%$ and the difference in elevation is about $1000-1200 \mathrm{~m}$, yielding an average deuterium depletion of about $5 \%$ per $100 \mathrm{~m}$ elevation, considered typical for southern Iceland (Árnason, 1976).

Fig. 10 compares $\delta^{18} \mathrm{O}$ and $\delta \mathrm{D}$ in the condensate gas samples $(n=2)$ from Hekla with other volcanic areas in Iceland, as well as with meteoric precipitation and groundwater. One of the Hekla condensate samples has $\delta \mathrm{D}$ similar to precipitation at low altitude near Hekla (200-400 m a.s.1.); while $\delta \mathrm{D}$ in the other gas sample is closer to that of Hekla summit precipitation ( 1500 m a.s.1.). Based on these results, we tentatively conclude that the water in the gas samples is a mixture of meteoric precipitation at various altitudes and local groundwater. Magmatic origin for the water vapour is unlikely.

The $\delta^{18} \mathrm{O}$ in the gas samples falls notably far to the left of GMWL (Fig. 10). A shift in $\delta^{18} \mathrm{O}$ towards more depleted values has been reported in cold, $\mathrm{CO}_{2}$-rich waters from other volcanically active areas in Iceland (Snæfellsnes, Arnórsson and Barnes, 1983; Kristmannsdóttir and Sveinbjoernsdóttir, 2012); Brimstone Basin in Yellowstone national park (Bergfeld et al., 2012); Malawi Rift in Tanzania (Delalande et al., 2011), as well as from several non-volcanic areas with high $\mathrm{CO}_{2}$ flux (Vuataz and Goff, 1986; Matthews et al., 1987; Pauwels et al., 1997; Cartwright et al., 2002). The operating mechanism is believed to be isotopic equilibration between $\mathrm{CO}_{2}$ from a deep thermal source and shallow, cold, groundwater (Bergfeld et al., 2012 and references therein). Fig. 10 also shows isotopic composition of water from volcanic systems with active geothermal systems (Darling and Ármannsson, 1989; Pope et al., 2009). Deep geothermal fluid tends to plot to the right of GMWL being less $\delta^{18} \mathrm{O}$ depleted than the local groundwater. On the other hand, surface fumaroles in geothermal volcanic systems are, to a variable extent, more depleted in both $\delta^{18} \mathrm{O}$ and $\delta \mathrm{D}$ than both the geothermal fluid and the local groundwater. This has been attributed to a variable degree of geothermal boiling and rock-water interaction (Darling and Ârmannsson, 1989). Our isotopic data alone cannot distinguish whether the depleted $\delta^{18} \mathrm{O}$ content of Hekla water vapour is a result of geothermal boiling, or an interaction of deep $\mathrm{CO}_{2}$ rich gas and cold groundwater. However, the circumstances at Hekla point towards the latter as there is little evidence for geothermal boiling (as discussed in 4.2, the gas composition is 




Fig. 10. Isotopic composition of $\delta \mathrm{D}$ and $\delta^{18} \mathrm{O}$ measured in condensate gas samples from Hekla in 2012, compared with local precipitation (low altitude and the summit), local groundwater (cold springs), as well as other volcanic systems in Iceland. Arrows show processes which are suggested to control the variability in $\delta \mathrm{D}$ and $\delta^{18} \mathrm{O}$ relative to the global meteoric water line (GMWL). The two Hekla gas samples have different $\delta \mathrm{D}$ which we believe indicates that they origin from precipitation at different altitudes. Depletion in $\delta^{18} \mathrm{O}$ in the Hekla gas is attributed to isotopic equilibration between deep-sourced $\mathrm{CO}_{2}$-rich gas and cold groundwater; the same mechanism has been postulated for $\mathrm{CO}_{2}$-rich cold groundwater springs at Snæfellsnes (see text for more detail). Fumarolic vapour samples from volcanic geothermal systems (Krafla, Námafjall and Theistareykir) show variable depletion in both $\delta \mathrm{D}$ and $\delta^{18} \mathrm{O}$ which has been attributed to geothermal boiling and rockwater interaction. The water in the volcanic geothermal system of Reykjanes is marine and therefore highly enriched in $\delta \mathrm{D}$ and $\delta^{18} \mathrm{O}$. References: Hekla gas, and summit precipitation (this study); Hekla cold springs (Gislason et al., 1992; Holm et al., 2010); Hekla low altitude precipitation (Árnason, 1976); Theistareykir, Krafla, Námafjall (Arnórsson and Barnes, 1983; Sveinbjornsdottir et al., 1986; Darling and Ármannsson, 1989); Hveragerdi, Leirá (Arnórsson and Barnes, 1983); Reykjanes (Ólafsson and Riley, 1978; Arnórsson and Barnes, 1983; Pope et al., 2009); GMWL (Craig, 1961).

$\mathrm{CO}_{2}$ - rather than $\mathrm{H}_{2} \mathrm{O}$ dominated). The temperature gradient in exploratory boreholes indicates a low-temperature system and there is no evidence for geothermal contribution to the local groundwater (e.g. Gislason et al., 1992; Hjartarson and Sigurðsson, 2000).

\subsection{Reaction path model results}

The calculated chemical compositions (proportions of $\mathrm{CO}_{2}, \mathrm{H}_{2} \mathrm{O}$ and $\mathrm{H}_{2} \mathrm{~S}$ in $\mathrm{vol} \%$ ) of the gas separated from the various over-saturated end-of-run aqueous solutions are shown in Fig. 5. These compositions would be representative of that of a residual gas formed after different extents of scrubbing of an initial deep gas by groundwater reactions (Fig. 4).

Simulation results highlight a range of residual gas compositions for the various runs (Fig. 5): in more gas-rich, higher-temperature runs (gas/water ratios $\sim 0.1$ ), representative of lower extents of scrubbing, the residual gas typically has more hydrous $\left(\mathrm{H}_{2} \mathrm{O} \sim 80.3, \mathrm{CO}_{2} \sim 19.7\right.$ vol\%) composition; while in lower-temperature, less gas rich (gas/water ratios $<0.02$ ) runs (more scrubbing), $\mathrm{CO}_{2}$ prevails $\left(\mathrm{H}_{2} \mathrm{O}\right.$ $\sim 1.3 \%, \mathrm{CO}_{2} \sim 98.7 \%$ ). The $\mathrm{H}_{2} \mathrm{O}-\mathrm{CO}_{2}$ composition of the residual gas is only marginally affected by changes in the composition of the initial deep gas (for the range of conditions included), and by the presence/absence of solid reactants (model results are somewhat overlapping in Hekla-Fimmvörduháls, Hekla-Surtsey and Hekla-Glass runs). For all run conditions, sulphur remains a trace component $\left(\sim 10^{-3}\right.$ to $\left.10^{-4} \mathrm{vol} \%\right)$ of the residual gas, and is invariably present in $\mathrm{H}_{2} \mathrm{~S}$ form (contrary to the initial gas(es), where $\mathrm{SO}_{2}$ prevailed). The most $\mathrm{S}$-depleted compositions $\left(\mathrm{H}_{2} \mathrm{~S}\right.$ $\sim 10^{-4} \mathrm{vol} \%$ ) are observed in the presence of a solid reactant (Hekla-Glass runs). This can be explained by $\mathrm{pH}$-control on gas-water sulphur-partitioning: compared to the very acidic ( $\mathrm{pH} \sim 1$ ) conditions of gas-water (Hekla-Fimmvörduháls, Hekla-Surtsey) runs (which favour $\mathrm{H}_{2} \mathrm{~S}$ degassing), neutral $\mathrm{pH} \sim 7$ conditions are observed in runs where the buffering role of rocks is taken into account (Hekla-Glass runs), leading to more effective $\mathrm{S}$ scrubbing to the liquid phase. However, the gas-neutralization role played by dissolution of the solid reactant is minimized in Hekla Glass 2 run at higher gas/water ratios as a consequence of faster gas dissolution relative to glass (Fig. 5).

The results of model simulations are compared in Fig. 8 with the compositions of natural (volcanic gas) samples from Iceland. The modelled residual gas compositions are remarkably different from the compositions of high-temperature magmatic gases measured during eruptions in Iceland (Sigvaldason and Elisson, 1968; Gerlach, 1980; Allard et al., 2010; Burton et al., 2010). The modelled residual gases have far lower sulphur contents and more $\mathrm{CO}_{2}$-enriched compositions $\left(\mathrm{CO}_{2} / \mathrm{S}_{\mathrm{TOT}}\right.$ from $\sim 220$ to $\left.\sim 308,000\right)$ than Icelandic magmatic gases $\left(\mathrm{S}_{\mathrm{T}} \sim 3 \mathrm{vol} \%\right.$ and $\mathrm{CO}_{2} /$ $\mathrm{S}_{\text {TOT }}$ of 0.1-5). Clearly, the model calculations account well for the extensive removal of reactive sulphur from the initial deep gas upon interaction with the groundwater systems (Symonds et al., 2001). There is also a mismatch between 
modelled and magmatic gas $\mathrm{H}_{2} \mathrm{O} / \mathrm{CO}_{2}$ compositions, with residual gases being typically less hydrous $\left(\mathrm{H}_{2} \mathrm{O} / \mathrm{CO}_{2}\right.$ range from 0.01 to 5.3). At the under-boiling conditions explored here, $\mathrm{CO}_{2}$ is the favourite gas species reaching the surface following scrubbing. Importantly, Fig. 8 demonstrates that the modelled residual gas compositions overlap with the compositional field of Hekla surface gas emissions measured in 2012-2013. The best fit between the modelled and measured Hekla gas is given by Hekla-Glass 2 run (Fig. 8). The faster gas dissolution rate used in HeklaGlass2 produces lower $\mathrm{CO}_{2} / \mathrm{S}_{\text {tot }}$ compositions as less sulphur is being scavenged by secondary minerals, which in turn gives a better fit between modelled and measured compositions.

\section{DISCUSSION}

\section{1 Origin of Hekla gas emissions}

The Hekla gas is chemically distinct from the compositional domain of steam samples from hydrothermal manifestations around active volcanic systems in Iceland (Fig. 8). While a pure hydrothermal derivation can be ruled out for the Hekla gas (based on $\mathrm{CO}_{2}$-dominated gas composition), a magmatic derivation is problematic, too: our Hekla gas differs in composition, being less hydrous and more sulphur-depleted, from compositions of magmatic gases emitted during subaerial eruptions in Iceland such as Eyjafjallajökull in 2010 (Allard et al., 2010; Burton et al., 2010) and Surtsey in 1964-67 (Sigvaldason and Elisson, 1968; Gerlach, 1980), see Fig. 8.

Magmatic gas supply to Hekla in 2012-2013 is strongly supported by the $\mathrm{CO}_{2}$ isotope measurements (Section 3.3), which identify a $\delta^{13} \mathrm{C}$ of $-4.0 \pm 0.6 \%$, consistent with the magmatic $\delta^{13} \mathrm{C}$ range in Iceland (Marty et al., 1991; Poreda et al., 1992). In light of this, and in order to reconcile the unusual $\mathrm{CO}_{2}$-rich composition of Hekla gas with its (at least partial) magmatic derivation, two hypotheses can be proposed:

(i) The gas supply to Hekla fumaroles during the quiescent interval was essentially contributed by a deep magmatic source (at least $200 \mathrm{MPa}$, or $10 \mathrm{~km}$ depth, Papale et al., 2006), with confining pressures high enough to allow substantial exsolution of only the scantily soluble $\mathrm{CO}_{2}$, with most of the more soluble $\mathrm{H}_{2} \mathrm{O}$ and sulphur remaining dissolved in the silicate melt.

(ii) The magmatic gas supply to Hekla was originally rich in both $\mathrm{H}_{2} \mathrm{O}$ and sulphur (e.g., similar for instance to the Fimmvörduháls gas measured by Burton et al. (2010); see Fig. 8) as it separated from magma at depth; but then underwent substantial modification by secondary processes during cooling and interaction with wall-rocks and groundwater along its pathway to surface (Fig. 4). The low temperature of surface manifestations strongly support that significant $\mathrm{H}_{2} \mathrm{O}$ condensation occurs prior to emission, a process which would also remove a substantial fraction of water-soluble sulphur. Scrubbing of $\mathrm{H}_{2} \mathrm{~S}$ (and eventually $\mathrm{SO}_{2}$ ) via heterogeneous reactions with groundwater, minerals and rocks would also be extremely likely in the low- $T$, low gas flux regime environment prevailing on Hekla during the quiescent interval. Condensation and scrubbing, if taking place to a significant extent, would overall lead to the increase in the concentration of the less reactive $\mathrm{CO}_{2}$ and to the depletion of the two other gases (Symonds et al., 2001; Werner et al., 2012; and references therein)

Mechanisms (i) and (ii) do not exclude each other, and may concur to produce the $\mathrm{CO}_{2}$-rich composition of Hekla gas (Fig. 8), but we believe that mechanism (ii) is the more plausible pathway as is explained in the following Sections 4.2 and 4.3).

\subsection{Interaction between volcanic gases and groundwater at Hekla}

The isotopic composition of $\mathrm{H}_{2} \mathrm{O}$ gas in Hekla's emissions (depleted in ${ }^{18} \mathrm{O}$ compared to the local precipitation and groundwater, Fig. 10) provides supporting evidence for a deep-sourced $\mathrm{CO}_{2}$ interacting with the shallow groundwater system. The groundwater in Hekla area has a stable, low temperature of $\sim 4^{\circ} \mathrm{C}$ (e.g. (Flaathen et al., 2009), which is favourable for rapid isotopic equilibration (Friedman and O'Neil, 1977; and references therein). Isotopic equilibration between deep-sourced $\mathrm{CO}_{2}$ with cold groundwater enriches $\mathrm{CO}_{2}$ in $\delta^{18} \mathrm{O}$ while $\mathrm{H}_{2} \mathrm{O}$ becomes relatively depleted; this has been observed in several areas with high $\mathrm{CO}_{2}$ degassing (Arnórsson and Barnes, 1983; Vuataz and Goff, 1986; Matthews et al., 1987; Pauwels et al., 1997; Cartwright et al., 2002; Delalande et al., 2011; Bergfeld et al., 2012).

Uptake of Hekla's magmatic gases by the surrounding groundwater system has been examined by Flaathen and Gislason (2007), Flaathen et al. (2009) and Gislason et al. (1992). Waters from groundwater springs $(n=26)$ and larger rivers $(n=4)$ sourced in Hekla area were analysed for concentrations of dissolved inorganic carbon (DIC) in irregular campaign measurements between 1988 and 2006. Flaathen et al. (2009) estimated the annual volcanic $\mathrm{CO}_{2}$ flux from Hekla based on the measured DIC concentration and the annual mean water discharge. It is interesting to compare the diffuse degassing $\mathrm{CO}_{2}$ flux (this study) and groundwater-transported flux (Flaathen et al., 2009) as is done in Table 5. There is a fairly large uncertainty associated with this comparison, since the groundwater measurements of Flaathen et al. (2009) were not made synchronously with our gas measurements. However, recent measurements in Hekla's spring waters (JulyAugust 2013, Icelandic Meteorological Office, monitoring data) revealed similar DIC concentrations to those reported by Flaathen et al. (2009), supporting the validity of the comparison. This comparison indicates that the diffuse degassing discharge of $\mathrm{CO}_{2}$ from Hekla's summit accounts for only $1.4-6.2 \%$ of the total $\mathrm{CO}_{2}$ flux from Hekla, with the rest being transported by groundwater. Note that this estimate does not take into account the fraction of the 
Table 5

Comparison between the flux of $\mathrm{CO}_{2}$ degassed at the summit of Hekla, and $\mathrm{CO}_{2}$ transported by the Hekla groundwater system (Flaathen et al., 2009). It is estimated that the $\mathrm{CO}_{2}$ degassed at the summit may be only $1-6 \%$ of the total annual $\mathrm{CO}_{2}$ discharge from Hekla. The estimate does not take into account the unknown proportion of the gases taken up by mineral phases.

\begin{tabular}{lll}
\hline $\mathrm{CO}_{2}$ discharge & Min (kT/a) & Max (kT/a) \\
\hline Transported by groundwater & 99 & 258 \\
Degassed at the summit & 3.65 & 6.35 \\
Total & $\mathbf{1 0 3}$ & $\mathbf{2 7 5}$ \\
$\begin{array}{l}\text { Degassing at the summit as \% } \\
\text { of total discharge }\end{array}$ & $\mathbf{1 . 4}$ & $\mathbf{6 . 2}$ \\
\hline
\end{tabular}

The bold values represent the total values, and percentage of total discharge, respectively. They represent the total system.

${ }^{*}$ Flaathen et al., 2009.

gas taken up by solid mineral phases. It must also be noted that our calculation of the total $\mathrm{CO}_{2}$ flux from Hekla is a minimum value, as it is based on a small high-flux area at the volcano's summit and omits potential low-flux emissions from other parts of the mountain, which are, nevertheless, extensive. This highlights the high probability of underestimating total fluxes from volcanic areas, as very low-emission areas are often excluded from field surveys. As shown in Section 3.1, the total $\mathrm{CO}_{2}$ flux from Hekla central volcano could be as high as $\sim 44 \mathrm{~T} \mathrm{~d}^{-1}$, or 3 times higher than the flux from the summit area. However, this does not change the conclusion that the $\mathrm{CO}_{2}$ content in groundwater far exceeds the diffuse degassing flux from the central volcano $\left(44 \mathrm{~T} \mathrm{~d}^{-1}\right.$ would account for a maximum of $15 \%$ of the total flux). The high volume of groundwater in the Hekla area and its low temperature $\left(\sim 4{ }^{\circ} \mathrm{C}\right)$ are likely contributing factors.

Gislason et al. (1992) report significant concentration of sulphate in Hekla's groundwaters, with mass flux of $2 \mathrm{~T} \mathrm{~h}^{-1}$ of $\mathrm{SO}_{4}$ compared to $8 \mathrm{~T} \mathrm{~h}^{-1}$ of $\mathrm{CO}_{2}$. The spatial distribution of these elevated concentrations support that their origin is primarily magmatic degassing rather than rock dissolution, as their abundance decreases rapidly with distance from the central volcano, in spite of small difference in bedrock composition. The fact that sulphur emissions at the summit of Hekla are negligible compared to $\mathrm{CO}_{2}$ (mean molar ratio $7600 \pm 8300$ ) strongly supports mechanism (ii) described in the previous section, where the original composition of gas released from Hekla contains both $\mathrm{H}_{2} \mathrm{O}$ and sulphur (in addition to $\mathrm{CO}_{2}$ ) but the more soluble components get removed through interaction with groundwater. We note that the $\mathrm{C} / \mathrm{S}$ ratio reported by Gislason et al. (1992) is higher (molar $\mathrm{C} / \mathrm{S} \sim 4$ ) than that predicted by our reaction path model for the liquid phase following scrubbing of magmatic gas (molar $\mathrm{C} / \mathrm{S} 0.5-0.6$ in a 50 $70{ }^{\circ} \mathrm{C}$ range). However, this difference is not surprising as the liquids in our model are representative of direct interaction with high- $T$ magmatic gases and consequently have low pH. In contrast, Gislason et al. (1992) studies cold spring water with near-neutral $\mathrm{pH}$, located several $\mathrm{km}$ from the volcano and therefore representative of later, more mature, stages of water-rock interactions.
As shown in Fig. 8 our modelled residual gas compositions (i.e., magmatic gas which has reacted with cold groundwater and wall-rock) overlap with the compositional field of Hekla surface gas emissions in 2012-2013. This overall agreement between modelled and measured compositions are consistent with the hypothesis that present-day Hekla gas manifestations are the end-product of extensive groundwater/hydrothermal scrubbing of deep magmatic gases. If this interpretation is correct, our results then also imply that the time-variability of gas compositions observed at Hekla today are sensitive to changes in (i) magmatic gas vs. meteoric water supply; (ii) composition of the feeding gas; (iii) extent of reaction with host rocks; (iv) extent of condensation in the soil, prior to atmospheric discharge (the soil is liquid-saturated in many areas of Hekla summit). If our interpretation of Hekla's degassing behaviour is correct, it can be predicted that the $\mathrm{CO}_{2}$ discharge may proportionally increase with building pressure in the magma source, and that the sulphur $/ \mathrm{CO}_{2}$ ratio becomes higher in the diffuse gas emissions as the influence of groundwater scrubbing is reduced.

\subsection{Subsurface structure}

The gas emissions at Hekla (in the form of diffuse soil degassing) were restricted to a small area $(\sim 400 \times 75 \mathrm{~m})$ at the volcano's summit crater (Fig. 3). The total $\mathrm{CO}_{2}$ flux $(\sim 5000 \mathrm{~T} / \mathrm{a}$ measured at the summit, plus estimated $\sim 10,000 \mathrm{~T} / \mathrm{a}$ from its flanks) is relatively low when compared to other degassing volcanoes in Iceland and elsewhere (see overview in Burton et al., 2013). However, it is noteworthy that point values of $\mathrm{CO}_{2}$ flux (up to $23,000 \mathrm{~g} \mathrm{~m}^{-2}$ $\mathrm{d}^{-1}$ ) were the highest that have been measured using same methodology in Iceland $\left(\max \sim 2200 \mathrm{~g} \mathrm{~m}^{-2} \mathrm{~d}^{-1}\right.$ at Reykjanes, Fridriksson et al., 2006; and 18,000 $\mathrm{g} \mathrm{m}^{-2} \mathrm{~d}^{-1}$ at Hengill, Hernández et al., 2012). The fact that the gas emissions were so spatially restricted may suggest a structural control on the degassing pathway. The spatial restriction of the gas emissions is further highlighted by comparison between the 'hot ground' areas at Hekla. It is well established that diffuse gas emissions tend to correlate with elevated ground temperatures (e.g., Fridriksson et al., 2006). At Hekla, however, it is noteworthy that there are areas outside the summit crater which have elevated ground temperatures $\left(T_{\mathrm{G}}\right)$, but no detectable gas emissions (Fig. 3). Öxl crater was the most remarkable example as it had higher $T_{\mathrm{G}}$ than the summit crater, but $\mathrm{CO}_{2}$ flux was always below, or barely above, the detection limit. This is particularly interesting when we consider the eruption history of the two craters: Öxl crater has been active in the two most recent eruptions (1991 and 2000) while the summit crater has not produced eruptive material since the eruption episodes in 1980-81 (Figs. 1 and 3).

Several structural models of Hekla's plumbing system assumed a deep magma reservoir $(>10 \mathrm{~km})$ and a narrow dyke which opens from the reservoir to the surface only during eruptions (e.g., Ofeigsson et al., 2011; Geirsson et al., 2012). This plumbing model presents some problems when trying to explain the observed degassing behaviour of Hekla: (i) it cannot explain the obvious spatial restriction 
of the diffuse gas flux; and (ii) the confining pressure at $>10 \mathrm{~km}$ depth would prohibit extensive exsolution of sulphur. This disagrees with petrological analysis of recently erupted Hekla's magmas which indicates significant loss of sulphur from the melt during storage at depth through fractional crystallisation and evolution of the primitive magma (Moune et al., 2007). Our measurements of the gas composition find that the emissions are sulphur-poor, but we explain this through scrubbing of soluble gases by shallow groundwater. This is in agreement with previous study by Gislason et al. (1992) which showed that large concentrations of sulphur are released by Hekla during non-eruptive periods and transported by groundwater (see Section 4.2).

In a recent publication Sturkell et al. (2013) propose a new structural model for Hekla's plumbing system which may be more consistent with our observations of the degassing pattern. Their model proposes that during the last large eruption of Hekla (1947 CE), a single and relatively large conduit formed. Due to its size, the conduit ( $\sim 50 \mathrm{~m}$ in diameter) has remained molten between eruptions in the recent decades. It extends from the deep reservoir $(\sim 10 \mathrm{~km})$ up to $<1 \mathrm{~km}$ depth below the surface, and during an eruption a shallow dyke breaks through the top $\sim 1 \mathrm{~km}$. This model fits with the observed patterns of shallow seismicity and GPS displacement, as well as providing an explanation for the recent decrease in eruption repose length from $\sim 60$ years to $\sim 10$ years (Sturkell et al., 2013).

Our $T_{\mathrm{G}}$ and $\mathrm{CO}_{2}$ flux measurements are consistent with the model suggested by Sturkell et al. (2013). We interpret our observations as follows: the elevated $T_{\mathrm{G}}$ at Öxl crater is residual heat in the dyke which fed the most recent eruption(s). The residual magma has lost its $\mathrm{CO}_{2}$ which accounts for the lack of detectable gas flux at the surface in spite of elevated $T_{\mathrm{G}}$. On the other hand, the gas flux (and heat flux) at the summit crater is driven by ongoing degassing of magma at depth $(\sim 10 \mathrm{~km})$. The model would also explain why the observed gas flux is spatially constrained to the summit crater, as exsolved gas would preferentially travel to the surface along the molten conduit. In addition, the estimated size of the molten conduit (Sturkell et al., 2013) is consistent with the size of the area with high gas emissions. However, a completely crystallized but fractured/porous conduit would also be consistent with the spatial distribution of the gas emissions at the summit. Both of these plumbing models allow for the exsolved gas composition to contain significant amounts of sulphur and $\mathrm{H}_{2} \mathrm{O}$ prior to being modified by groundwater interaction (see Section 4.2).

\section{CONCLUSIONS}

Our study at Hekla volcano provides the first measurements of its atmospheric gas flux during a quiescent interval (2012-2013). The gas composition was $\mathrm{CO}_{2}$-dominated ( 0.79 mol fraction) and chemically distinct both from the compositional domain of steam samples from hydrothermal manifestations around active volcanic systems in Iceland (less hydrous), as well as from syn-eruptive magmatic gases (more sulphur-depleted).

The total $\mathrm{CO}_{2}$ flux from Hekla mountain (in the form of diffuse soil degassing) was calculated to be at least $44 \mathrm{~T} \mathrm{~d}^{-1}$, thereof $14 \mathrm{~T} \mathrm{~d}^{-1}$ were sourced from a very small area $(\sim 400 \times 75 \mathrm{~m})$ at the volcano's summit. The individual point values are the highest known in Iceland. The origin of the $\mathrm{CO}_{2}$ is believed to be magmatic based on ${ }^{13} \mathrm{C}$ signature. The summit was the only area on Hekla mountain with both elevated ground temperature as well as detectable gas flux, while several areas on the flanks displayed elevated $T_{\mathrm{G}}$ but had very low or negligible gas flux. Our interpretation is that the elevated $T_{\mathrm{G}}$ on the flanks is due to residual heat in the intrusion from the most recent eruption(s). On the other hand, the gas flux in the summit area is sourced in a degassing magma body at depth $(\sim 10 \mathrm{~km})$. The structural model of the plumbing system proposed by Sturkell et al. (2013) is consistent with the spatial restriction of the gas emissions to the summit crater area.

Based on the combined observations of the field data and reaction path modelling results, we conclude that the gas composition is rich in $\mathrm{H}_{2} \mathrm{O}, \mathrm{CO}_{2}$ and sulphur when it separates from the magma body at depth, but undergoes substantial modification along its pathway to the surface through cooling and interaction with wall-rock and groundwater. The modification involves both significant $\mathrm{H}_{2} \mathrm{O}$ condensation and scrubbing of S-bearing species, leading to a $\mathrm{CO}_{2}$-dominated gas composition at the surface. Only a small fraction of the discharged gas $(<15 \%)$ reaches Hekla's summit during quiescent intervals, with the rest being taken up and transported by groundwater (the proportion taken up by mineral phases is unknown). A compositional shift towards more $\mathrm{S}-$ and $\mathrm{H}_{2} \mathrm{O}$-rich gas compositions if measured in the future by the permanent MultiGAS station should be viewed as sign of imminent volcanic unrest on Hekla.

\section{ACKNOWLEDGEMENTS}

The research leading to these results has received funding from the Icelandic Centre for Research (RANNIS, grant number 110002-0031); the European Community's Seventh Framework Programme under Grant Agreement No. 308377 (Project FUTUREVOLC); and the International Civil Aviation Organization. Mauro Martelli and Andrea Rizzo at INGV Palermo are thanked for the gas chromatography and isotope analysis. Árný Erla Sveinbjörnsdóttir at the Institute of Earth Sciences, University of Iceland is thanked for the mass spectrometry analysis. The Icelandic Coast Guard and the Department of Civil Protection of the National Commissioner of the Icelandic Police are gratefully acknowledged for airlifting the permanent station to the top of Hekla. Björn Oddsson and Sigrún Karlsdóttir are personally thanked for their involvement in this matter. Vilhjálmur S. Kjartansson, Jón Bjarni Friðriksson, Bergur H. Bergsson, Porgils Ingvarsson, Ólafur Freyr Gíslason, Vincenzo Francofonte and pilots of the Icelandic Coast Guard receive our gratitude for their assistance and invaluable know-how in challenging field conditions. Guðrún Nína Petersen is warmly thanked for help with meteorological data.

\section{APPENDIX A. SUPPLEMENTARY DATA}

Supplementary data associated with this article can be found, in the online version, at http://dx.doi.org/10.1016/ j.gca.2015.01.013. 


\section{REFERENCES}

Aiuppa A., Federico C., Giudice G., Giuffrida G., Guida R., Gurrieri S., Liuzzo M., Moretti R. and Papale P. (2009) The 2007 eruption of Stromboli volcano: insights from real-time measurement of the volcanic gas plume $\mathrm{CO}_{2} / \mathrm{SO}_{2}$ ratio. $J$. Volcanol. Geoth. Res. 182, 221-230.

Aiuppa A., Burton M. R., Caltabiano T., Giudice G., Guerrieri S., Liuzzo M., Mure F. and Salerno G. G. (2010) Unusually large magmatic $\mathrm{CO} 2$ gas emissions prior to a basaltic paroxysm. Geophys. Res. Lett. 37, L17303.

Allard P., Burton M. R., Oskarsson N., Michel A. and Polacci M. (2010) Chemistry and fluxes of magmatic gases powering the explosive trachyandesitic phase of Eyjafjallajokull 2010 eruption: constraints on degassing magma volumes and processes. In Presented at the AGU Fall Meeting. AGU, San Francisco, California.

Árnason B. (1976). Groundwater Systems in Iceland Traced by Deuterium. Prentsmidjan Leiftur HF.

Arnórsson S. and Barnes I. (1983) The nature of carbon dioxide waters in Snaefellsnes, western Iceland. Geothermics 12, 171-176.

Bergfeld D., Evans W. C., Lowenstern J. B. and Hurwitz S. (2012) Carbon dioxide and hydrogen sulfide degassing and cryptic thermal input to Brimstone Basin, Yellowstone National Park, Wyoming. Chem. Geol. 330-331, 233-243.

Burton M. R., Salerno G. G., La Spina A., Stefansson A. and Kaasalainen H. (2010) Measurements of volcanic gas emissions during the first phase of 2010 eruptive activity of Eyjafallajokull. In Presented at the AGU Fall Meeting. AGU, San Francisco, California.

Burton M. R., Sawyer G. M. and Granieri D. (2013) Deep carbon emissions from volcanoes. Rev. Mineral. Geochem. 75, 323-354.

Cardellini C., Chiodini G. and Frondini F. (2003) Application of stochastic simulation to $\mathrm{CO}_{2}$ flux from soil: mapping and quantification of gas release. J. Geophys. Res. 108, 2425.

Cartwright I., Weaver T., Tweed S., Ahearne D., Cooper M., Czapnik K. and Tranter J. (2002) Stable isotope geochemistry of cold CO2-bearing mineral spring waters, Daylesford, Victoria, Australia: sources of gas and water and links with waning volcanism. Chem. Geol. 185, 71-91.

Chiodini G. and Marini L. (1998) Hydrothermal gas equilibria: the $\mathrm{H}_{2} \mathrm{O}-\mathrm{H}_{2}-\mathrm{CO}_{2}-\mathrm{CO}-\mathrm{CH}_{4}$ system. Geochim. Cosmochim. Acta 62 , 2673-2687.

Craig H. (1961) Isotopic variations in meteoric waters. Science 133, 1702-1703.

Darling W. G. and Ármannsson H. (1989) Stable isotopic aspects of fluid flow in the Krafla, Námafjall and Theistareykir geothermal systems of northeast Iceland. Chem. Geol. 76, 197-213. http://dx.doi.org/10.1016/0009-2541(89)90090-9.

Delalande M., Bergonzini L., Gherardi F., Guidi M., Andre L., Abdallah I. and Williamson D. (2011) Fluid geochemistry of natural manifestations from the Southern Poroto-Rungwe hydrothermal system (Tanzania): Preliminary conceptual model. J. Volcanol. Geoth. Res. 199, 127-141. http://dx.doi.org/ 10.1016/j.jvolgeores.2010.11.002.

Di Napoli R., Aiuppa A. and Allard P. (2014) First Multi-GAS based characterisation of the Boiling Lake volcanic gas (Dominica, Lesser Antilles). Ann. Geophys. 56(5), 2013.

Flaathen T. and Gislason S. R. (2007) The effect of volcanic eruptions on the chemistry of surface waters: the 1991 and 2000 eruptions of Mt. Hekla, Iceland. J. Volcanol. Geoth. Res. 164, 293-316.

Flaathen T., Gislason S. R., Oelkers E. and Sveinbjornsdottir A. (2009) Chemical evolution of the Mt. Hekla, Iceland, groundwaters: a natural analogue for $\mathrm{CO}_{2}$ sequestration in basaltic rocks. Appl. Geochem. 24, 463-474.
Fridriksson T., Kristjansson B. R., Armannsson H., Margretardottir E., Olafsdottir S. and Chiodini G. (2006) $\mathrm{CO} 2$ emissions and heat flow through soil, fumaroles, and steam heated mud pools at the Reykjanes geothermal area, SW Iceland. Appl. Geochem. 21, 1551-1569.

Friedman I. and O'Neil J. (1977) Compilation of stable isotope fractionation factors of geochemical interest. In Data of Geochemistry (ed. M. K. Fleischer). Professional Paper. US Dept. of the Interior, US Geological Survey, p. 60.

Geirsson H., LaFemina P., Árnadóttir T., Sturkell E., Sigmundsson F., Travis M., Schmidt P., Lund B., Hreinsdóttir S. and Bennett R. (2012) Volcano deformation at active plate boundaries: deep magma accumulation at Hekla volcano and plate boundary deformation in south Iceland. $J$. Geophys. Res. Solid Earth 117, B11409.

Gerlach T. M. (1980) Evaluation of volcanic gas analysis from Surtsey volcano, Iceland 1964-1967. J. Volcanol. Geoth. Res. 8, 191-198.

Giggenbach W. F. (1988) Geothermal solute equilibria. Derivation of $\mathrm{Na}-\mathrm{K}-\mathrm{Mg}-\mathrm{Ca}$ geoindicators. Geochim. Cosmochim. Acta 52, 2749-2765.

Gislason S. R. and Eugster H. P. (1987) Meteoric water-basalt interactions. II: A field study in N.E Iceland. Geochim. Cosmochim. Acta 51, 2841-2855.

Gislason S. R. and Oelkers E. (2003) Mechanism, rates, and consequences of basaltic glass dissolution: II. An experimental study of the dissolution rates of basaltic glass as a function of $\mathrm{pH}$ and temperature. Geochim. Cosmochim. Acta 67, 3817-3832.

Gislason S. R., Andrésdóttir A., Sveinbjörnsdóttir Á., Oskarsson N., Thordarson T., Torssander P., Novâk M. and Zâk K. (1992) Local effects of volcanoes on the hydrosphere: example from Hekla, southern Iceland. Water-Rock Interact. Rotterdam, Balkema 1, 477-481.

Granieri D., Chiodini G., Marzocchi W. and Avino R. (2003) Continuous monitoring of $\mathrm{CO} 2$ soil diffuse degassing at Phlegraean Fields (Italy): influence of environmental and volcanic parameters. Earth Planet. Sci. Lett. 212, 167-179.

Gronvold K., Larsen G., Einarsson P., Thorarinsson S. and Saemundsson K. (1983) The Hekla eruption 1980-1981. Bull. Volcanologique 46, 349-363.

Gudmundsson A., Oskarsson N., Gronvold K., Saemundsson K., Sigurdsson O., Stefansson R., Gislason S. R., Einarsson P., Brandsdottir B., Larsen G., Johannesson H. and Thordarson T. (1992) The 1991 eruption of Hekla, Iceland. Bull. Volcanol. 54, 238-246.

Hedenquist J. W. and Lowenstern J. B. (1994) The role of magmas in the formation of hydrothermal ore deposits. Nature 370, 519527.

Helgeson H. C. (1968) Evaluation of irreversible reactions in geochemical processes involving minerals and aqueous solutions-I. Thermodynamic relations. Geochim. Cosmochim. Acta 32, $853-877$.

Helgeson H. C. (1979) Mass transfer among minerals and hydrothermal solutions. Geochem. Hydrothermal Ore Deposits 2, 568-610.

Helgeson H. C., Garrels R. M. and MacKenzie F. T. (1969) Evaluation of irreversible reactions in geochemical processes involving minerals and aqueous solutions-II. Applications. Geochim. Cosmochim. Acta 33, 455-481.

Hernández P., Pérez N., Fridriksson T., Egbert J., Ilyinskaya E., Thárhallsson A., Ívarsson G., Gíslason G., Gunnarsson I., Jónsson B., Padrón E., Melián G., Mori T. and Notsu K. (2012) Diffuse volcanic degassing and thermal energy release from Hengill volcanic system, Iceland. Bull. Volcanol. 74, 2435 2448. 
Hjartarson Á. and Sigurðsson F. (2000) Lindir og lindasvæði í Holta- og Landssveit (Open-file report No. OS-2000/054). Orkustofnun - Rannsóknarsvið.

Holm N. G., Gislason S. R., Sturkell E. and Torssander P. (2010) Hekla cold springs (Iceland): groundwater mixing with magmatic gases. Isot. Environ. Health Stud. 46, 180-189.

Höskuldsson Á., Óskarsson N., Pedersen R., Grönvold K., Vogfjörð K. and Ólafsdóttir R. (2007) The millennium eruption of Hekla in February 2000. Bull. Volcanol. 70, 169-182.

Kjartansson E. and Gronvold K. (1983) Location of a magma reservoir beneath Hekla Volcano, Iceland. Nature 301, 139-141.

Kristmannsdóttir H. and Sveinbjoernsdóttir Á. E. (2012) An anomalous thermal water from Hofsstadir western Iceland: Evidence for past CO2 flushing. Appl. Geochem. 27, 1146-1152.

Larsen G., Dugmore A. and Newton A. (1999) Geochemistry of historical-age silicic tephras in Iceland. Holocene 9, 463-471.

Marini L. and Gambardella B. (2005) Geochemical modeling of magmatic gas scrubbing. Ann. Geophys.

Marty B., Gunnlaugsson E., Jambon A., Oskarsson N., Ozima M., Pineau F. and Torssander P. (1991) Gas geochemistry of geothermal fluids, the Hengill area, southwest rift zone of Iceland. Chem. Geol. 91, 207-225.

Matthews A., Fouillac C., Hill R., O’Nions R. K. and Oxburgh E. R. (1987) Mantle-derived volatiles in continental crust: the Massif Central of France. Earth Planet. Sci. Lett. 85, 117-128.

Moune S., Gauthier P.-J., Gislason S. R. and Sigmarsson O. (2006) Trace element degassing and enrichment in the eruptive plume of the 2000 eruption of Hekla volcano, Iceland. Geochim. Cosmochim. Acta 70, 461-479.

Moune S., Sigmarsson O., Thordarson T. and Gauthier P.-J. (2007) Recent volatile evolution in the magmatic system of Hekla volcano, Iceland. Earth Planet. Sci. Lett. 255, 373-389.

Oelkers E. H. (2001) General kinetic description of multioxide silicate mineral and glass dissolution. Geochim. Cosmochim. Acta 65, 3703-3719.

Oelkers E. H., Schott J. and Gíslason S. (1999) Invited lecture: A general mechanism for multi-oxide solid dissolution and its application to basaltic glass. Geochem. Earth's Surf. Balkema, Rotterdam, 413-416.

Ofeigsson B., Hooper A., Sigmundsson F., Sturkell E. and Grapenthin R. (2011) Deep magma storage at Hekla volcano, Iceland, revealed by InSAR time series analysis. J. Geophys. Res. 116, B05401.

Ólafsson J. and Riley J. P. (1978) Geochemical studies on the thermal brine from Reykjanes (Iceland). Chem. Geol. 21, 219237. http://dx.doi.org/10.1016/0009-2541(78)90046-3.

Oskarsson N. (1980) The interaction between volcanic gases and tephra: fluorine adhering to tephra of the 1970 Hekla eruption. J. Volcanol. Geoth. Res. 8, 251-266.

Oskarsson N. (1984) Monitoring of fumarole discharge during the 1975-1982 rifting in Krafla volcanic center, north Iceland. $J$. Volcanol. Geoth. Res. 22, 97-121.

Papale P., Moretti R. and Barbato D. (2006) The compositional dependence of the saturation surface of $\mathrm{H}_{2} \mathrm{O}+\mathrm{CO}_{2}$ fluids in silicate melts. Chem. Geol. 229, 78-95.

Pauwels H., Fouillac C., Goff F. and Vuataz F.-D. (1997) The isotopic and chemical composition of $\mathrm{CO} 2$-rich thermal waters in the Mont-Dore region (Massif-Central, France). Appl. Geochem. 12, 411-427.

Pope E. C., Bird D. K., Arnórsson S., Fridriksson T., Elders W. A. and Fridleifsson G. O. (2009) Isotopic constraints on ice age fluids in active geothermal systems: Reykjanes, Iceland. Geochim. Cosmochim. Acta 73, 4468-4488.

Poreda R., Craig H., Arnórsson S. and Welhan J. (1992) Helium isotopes in Icelandic geothermal systems: I. 3He, gas chemistry, and 13C relations. Geochim. Cosmochim. Acta 56, 4221-4228.
Rose W., Gu Y., Watson I. M., Yu T., Bluth G., Prata A., Krueger A., Krotkov N., Carn S., Fromm M., Hunton D., Ernst G., Viggiano A., Miller T., Ballenthin J., Reeves J., Wilson J., Anderson B. and Flittner D. (2003) The February-March 2000 eruption of Hekla, Iceland from a satellite perspective. In Volcanism and the Earth's Atmosphere, Geophysical Monograph, pp. 109-132. Volcanism and the Earth's Atmosphere, Geophysical Monograph. American Geophysical Union.

Sigmundsson F., Einarsson P. and Bilham R. (1992) Magma chamber deflation recorded by the global positioning system: the Hekla 1991 Eruption. Geophys. Res. Lett. 19, 1483-1486.

Sigvaldason G. E. and Elisson G. (1968) Collection and analysis of volcanic gases at Surtsey Iceland. Geochim. Cosmochim. Acta 32, 797-805.

Soosalu H. and Einarsson P. (2004) Seismic constraints on magma chambers at Hekla and Torfajökull volcanoes, Iceland. Bull. Volcanol. 66, 276-286.

Sturkell E., Agustsson K., Linde A. T., Sacks S., Einarsson P., Sigmundsson F., Geirsson H., Pedersen R. and La Femina P. (2005) Geodetic constraints on the magma chamber of the Hekla volcano, Iceland. EOS Transactions, AGU 86, V21D-0636.

Sturkell E., Ágústsson K., Linde A. T., Sacks S. I., Einarsson P., Sigmundsson F., Geirsson H., Pedersen R., LaFemina P. C. and Ólafsson H. (2013) New insights into volcanic activity from strain and other deformation data for the Hekla 2000 eruption. J. Volcanol. Geoth. Res. 256, 78-86.

Sveinbjornsdottir A. E., Coleman M. L. and Yardley B. W. D. (1986) Origin and history of hydrothermal fluids of the Reykjanes and Krafla geothermal fields, Iceland. Contr. Mineral. Petrol. 94, 99-109. http://dx.doi.org/10.1007/ BF00371231.

Symonds R. B., Gerlach T. M. and Reed M. H. (2001) Magmatic gas scrubbing: implications for volcano monitoring. $J$. Volcanol. Geoth. Res. 108, 303-341.

Thorarinsson S. (1950) The eruption of Mt. Hekla 1947-1948. Bull. Volcanol. 10, 157-168.

Thorarinsson T. (1967) The eruption of Hekla 1947-48. 1-The eruptions of Hekla in historical times, a tephrochronological study. Soc. Sci. Isl., 1-170.

Thorarinsson S. and Sigvaldason G. E. (1972) The Hekla Eruption of 1970. Bull. Volcanol. 36, 269-288.

Vuataz F. D. and Goff F. (1986) Isotope geochemistry of thermal and nonthermal waters in the Valles Caldera, Jemez Mountains, Northern New Mexico. J. Geophys. Res. 91, $1835-1853$.

Werner C., Evans W., Kelly P., McGimsey R., Pfeffer M., Doukas M. and Neal C. (2012) Deep magmatic degassing versus scrubbing: Elevated $\mathrm{CO} 2$ emissions and $\mathrm{C} / \mathrm{S}$ in the lead-up to the 2009 eruption of Redoubt Volcano. Alaska. Geochem. Geophys. Geosyst. 13, Q03015.

Wolery T. J. (1992) EQ3/6: A software package for geochemical modeling of aqueous systems: Package overview and installation guide (version 7.0). Lawrence Livermore National Laboratory, Livermore, CA.

Wolery T. J. and Daveler S. A. (1992) EQ6, a computer program for reaction path modeling of aqueous geochemical systems: theoretical manual, user's guide and related documentation (Version 7.0). Lawrence Livermore Laboratory, University of California.

Wolff-Boenisch D., Gislason S. R., Oelkers E. H. and Putnis C. V. (2004) The dissolution rates of natural glasses as a function of their composition at $\mathrm{pH} 4$ and 10.6, and temperatures from 25 to $74^{\circ} \mathrm{C}$. Geochim. Cosmochim. Acta $\mathbf{6 8}, 4843-4858$.

Associate editor: Pete Burnard 